\title{
Treatment of industrial oily wastewater by advanced technologies: a review
}

\author{
Adegoke Isiaka Adetunji $^{1}$ [ $\cdot$ Ademola Olufolahan Olaniran ${ }^{1}$
}

Received: 20 January 2021 / Accepted: 18 May 2021 / Published online: 28 May 2021

(c) The Author(s) 2021

\begin{abstract}
Oily wastewater consists of fats, oils and greases together with a broad spectrum of dissolved organic and/or inorganic substances in suspension. It is regarded as one of the most hazardous wastewaters, causing serious environmental and health threats to the ecosystems, flora and fauna. The global increase in the discharge of oily wastewater coupled with stringent regulations for effluent discharge and incessant drive for re-use of treated wastewater necessitate the need for treatment of the wastewater. Conventional approaches employed in the past are inept for oily wastewater treatment due to low treatment efficiency and high operational costs, among others, hence the need for adoption of advanced technologies as promising alternatives to existing treatment systems for oily wastewater. Furthermore, the use of combined treatment processes is effective for the removal of hazardous pollutants present in high-strength oily wastewater. This review provides insights into advanced and emerging state-of-the-art technologies for safe and efficient treatment of industrial oily wastewater.
\end{abstract}

Keywords Oily wastewater $\cdot$ Advanced technologies $\cdot$ Treatment $\cdot$ Pollutants $\cdot$ Remediation

\section{Introduction}

Oily wastewater is defined as a wastewater that consists of fats, oils and greases coupled with a variety of dissolved substances (organic and/or inorganic) in suspension at high concentrations (Adetunji and Olaniran 2018; Wei et al. 2020). Oil-contaminated wastewater is produced from various industries including metal processing industries, restaurants, slaughterhouses, dairy industries, poultry processing industries, edible oil refineries, petrochemical industries, tannery industries, etc. (Adetunji 2017; Sungur and Özkan 2017; Adetunji and Olaniran 2018; Kuyukina et al. 2020; Sanghamitra et al. 2021) (Fig. 1). It is characterized by high biochemical oxygen demand (BOD), total suspended solids (TSS), chemical oxygen demand (COD), ammonia, sulphides, total organic carbon, total petroleum hydrocarbon (TPH) and other toxic compounds, based on the operations and products from the producing industries (Al Zarooni and Elshorbagy 2006; Diyauddeen et al. 2011; Tobiszewski et al.

Adegoke Isiaka Adetunji

adegokeadetunji8@gmail.com

1 Discipline of Microbiology, School of Life Sciences, University of KwaZulu-Natal (Westville Campus), Private Bag X54001, Durban 4000, Republic of South Africa
2012; Rahi et al. 2021) and (Table 1). It occurs as unstable/ highly stable oil-water emulsions or as free-floating oil, which are difficult to treat (Chen et al. 2000; Hanafy and Nabih 2007; Awaleh and Soubaneh 2014).

The production and discharge of raw and inadequately treated oily wastewater increase yearly owing to brisk urbanization and industrial growth (Affandi et al. 2014; Kuyukina et al. 2020). The oily wastewater-producing industries make use of huge volume of water for different operations (such as equipment and washing facilities, product production), leading to the generation of large amounts of wastewater with consequential upsurge in disposal and harsh pollution problems, thus resulting in environmental risks and hindering the normal operations of the ecosystems (Porwal et al. 2015).

Owing to strict policies for effluent discharge and incessant desire for re-use of treated water, treatment of oily wastewater has become imperative (Qin et al. 2007; Kuyukina et al. 2020). Factors such as wastewater composition (high, medium, or low strength), regulatory limitations, costs, treatment efficiency and end use of wastewater affect the selection of techniques for treatment of oily wastewater (Rajasulochana and Preethy 2016). Methods such as flotation, chemical coagulation, gravity separation and sedimentation are traditional approaches for the treatment of oily wastewater (Abuhasel et al. 2021). However, these techniques are insufficient due to operational 
Fig. 1 Schematic illustration showing various sources of oily wastewater

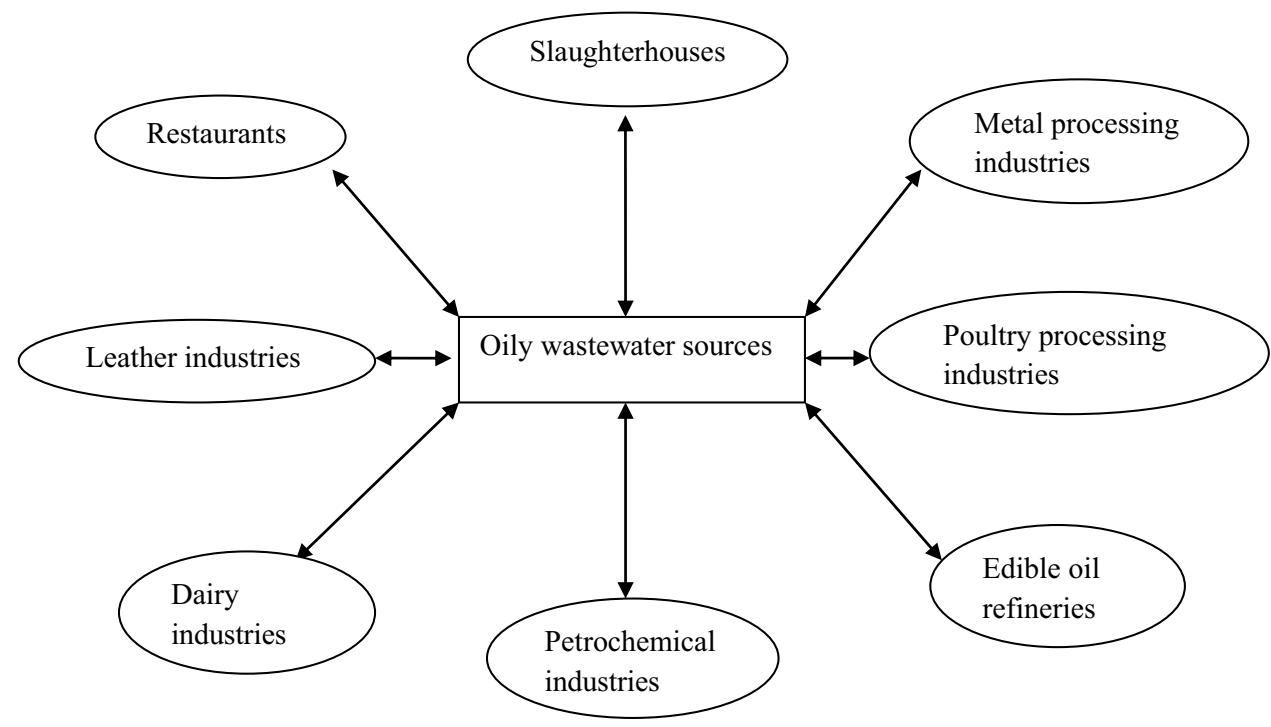

Table 1 Pollutant load of oily wastewater from some selected sources

\begin{tabular}{|c|c|c|c|c|c|c|c|c|c|}
\hline $\begin{array}{l}\text { Oily wastewa- } \\
\text { ter source }\end{array}$ & $\begin{array}{l}\text { O \& G con- } \\
\text { tent }(\mathrm{mg} / \mathrm{L})\end{array}$ & $\mathrm{BOD}_{5}(\mathrm{mg} / \mathrm{L})$ & $\mathrm{COD}(\mathrm{mg} / \mathrm{L})$ & TOC (mg/L) & TSS (mg/L) & TDS (mg/L) & $\mathrm{TN}(\mathrm{mg} / \mathrm{L})$ & $\mathrm{TP}(\mathrm{mg} / \mathrm{L})$ & Reference \\
\hline $\begin{array}{l}\text { Dairy waste- } \\
\text { water }\end{array}$ & 53,367 & 691 & 5693 & ND & 2333 & 5700 & 129 & 27.2 & $\begin{array}{l}\text { Adetunji and } \\
\text { Olaniran } \\
(2018)\end{array}$ \\
\hline $\begin{array}{l}\text { Poultry } \\
\text { processing } \\
\text { wastewater }\end{array}$ & 88,900 & 707 & 7518 & ND & 4667 & 807,000 & 79 & 24.3 & $\begin{array}{l}\text { Adetunji and } \\
\text { Olaniran } \\
(2018)\end{array}$ \\
\hline $\begin{array}{l}\text { Abattoir } \\
\text { wastewater }\end{array}$ & 2500 & - & 1367 & ND & 2822 & ND & ND & ND & $\begin{array}{l}\text { Osibanjo and } \\
\text { Adie (2007) }\end{array}$ \\
\hline $\begin{array}{l}\text { Petrochemi- } \\
\text { cal industry } \\
\text { wastewater }\end{array}$ & 1525 & 338.5 & 25,660 & ND & ND & ND & 2024 & 24.6 & $\begin{array}{l}\text { Wei et al. } \\
\text { (2020) }\end{array}$ \\
\hline $\begin{array}{l}\text { Tannery } \\
\text { industry } \\
\text { wastewater }\end{array}$ & 410 & 400 & 6200 & ND & 18,160 & ND & ND & ND & $\begin{array}{l}\text { Sungur and } \\
\text { Özkan } \\
(2017)\end{array}$ \\
\hline $\begin{array}{l}\text { Edible oil } \\
\text { industry } \\
\text { wastewater }\end{array}$ & 375 & 1932 & 12,880 & ND & 2850 & ND & 1261 & 583 & $\begin{array}{l}\text { Aslan et al. } \\
\text { (2009) }\end{array}$ \\
\hline
\end{tabular}

ND Not detected, TOC Total organic carbon, TN Total nitrogen, TP Total phosphorus

difficulties, high operational costs, release of secondary pollutants and low treatment efficiency (Guolin et al. 2011; Yu et al. 2017; Han et al. 2019). Advanced technologies are effective for oily wastewater treatment (Fig. 2). Therefore, this review elucidates emerging treatment approaches for efficient, sustainable, cost-effective and eco-friendly removal of hazardous pollutants from industrial oily wastewater.

\section{Environmental and health impacts of oily wastewater}

Oil-contaminated wastewater is regarded as one of the most potent and hazardous wastewater to the environments by the United States Environmental Protection Agency 
Fig. 2 Schematic diagram depicting advanced technologies for the treatment of industrial oily wastewater

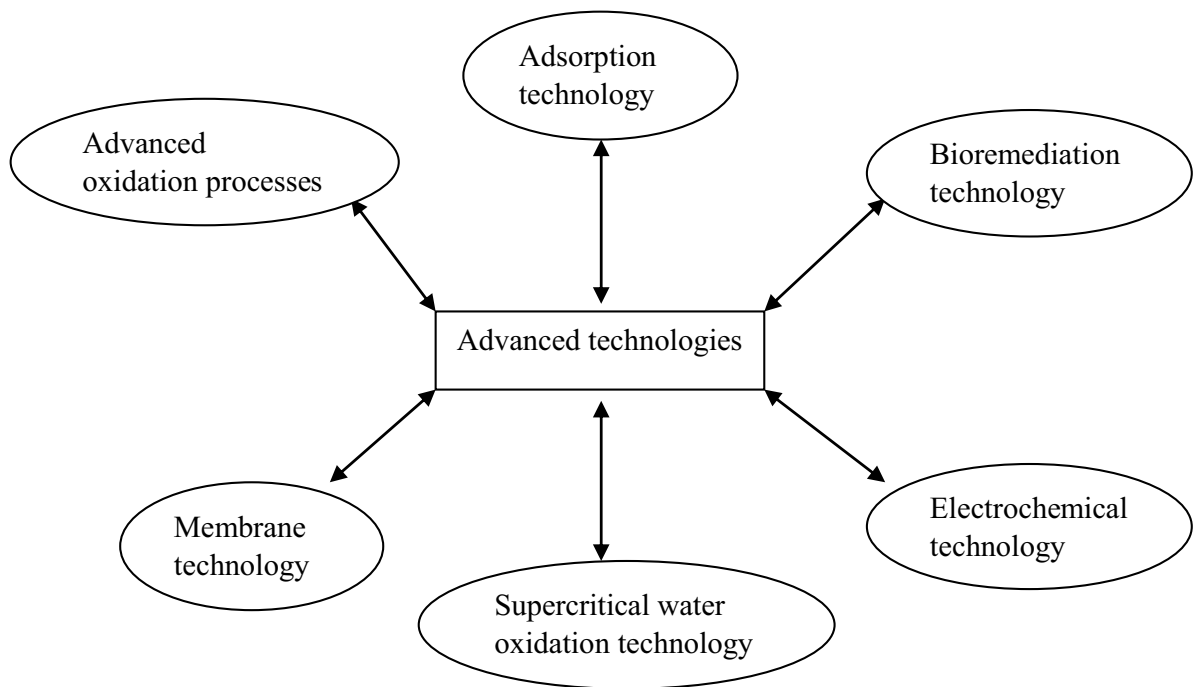

(USEPA) (USEPA 2004). The untreated and poorly treated oily wastewater, when improperly discharged, poses severe risks to the immediate environments by causing air pollution and contamination of surface and underground water (Shete and Shinkar 2013; Ibrahim et al. 2017). High-strength oily wastewater release into water bodies results in excessive consumption of dissolved oxygen by microorganisms (Attiogbe et al. 2007; Yazdan et al. 2020). This oxidizes the wastewater, thereby depleting the amount of oxygen needed for aerobic processes (Abd El-Gawad 2014). The presence of nitrogen and sulphurcontaining compounds such as ammonia and hydrogen sulphide, respectively, in oily wastewater causes toxic effects on aquatic ecosystems. They reduce the dissolved oxygen content of water bodies to levels inadequate for the survival of aquatic organisms (Poulton et al. 2002; Seveso et al. 2021). When the dissolved oxygen threshold limit is below $2 \mathrm{mg} / \mathrm{L}$, this eventually results in mass death of aquatic organisms (Attiogbe et al. 2007). The viscous nature of oil and grease $(\mathrm{O} \& \mathrm{G})$ in the wastewater causes blockage of drainage and sewer lines, which eventually corrode the sewer lines and generate obnoxious odor and unsightly appearance on the surface of receiving water bodies (Xu and Zhu 2004; Madaki and Seng 2013; He et al. 2015). Nutrients including nitrogen and phosphorus present in oily wastewater lead to eutrophication of receiving water bodies (Kushwaha and Srivastava 2011; Lürling and Mucci 2020). The presence of high suspended solids (SS) in oily wastewater slows down degradation rate and results in scum layer formation (Hejnfelt and Angelidaki 2009). In addition, phenolic compound-containing oily wastewater is toxic and carcinogenic and thus causes damage to the ecosystem in water bodies with resultant effects on humans (Lathasree et al. 2004; Pardeshi and Patil 2008; Yang et al. 2008; Abdelwahab et al. 2009; Mearns et al.
2020). In the agricultural sector, discharge of oily wastewater transforms the physico-chemical properties of the soil by adversely affecting its morphology, water absorption capacity and lessen the soil hygroscopic moisture and hydraulic conductivity (Trofimov and Rozanova 2003; Suleimanov et al. 2005; Robertson et al. 2007). This inhibits seed germination and permits plants' access to fewer nutrients, which ultimately results in limited plant growth (Al-Mutairi et al. 2008; Sutton et al. 2013).

\section{Advanced technologies for oily wastewater treatment}

\section{Microbial bioremediation technology}

Bioremediation is an emerging and state-of-the-art technology that employs metabolic potential of microorganisms for the removal of hazardous pollutants from oily wastewater under aerobic or anaerobic conditions, or a cocktail of both through complete degradation or sequestration (Chavan and Mukherji 2008; Chen et al. 2019; Sayed et al. 2021). The microbes use the pollutants as carbon source and convert them into innocuous products through secretion of suitable metabolites (Ławniczak et al. 2020; Yu et al. 2020; Adetunji and Olaniran 2021). The microbial activity depends on parameters such as temperature, $\mathrm{pH}$, toxic elements, presence or absence of oxygen, moisture, redox potential, retention times and organic contents. Bioremediation is a preferred method nowadays when compared to other technologies for oily wastewater treatment owing to its costeffectiveness, eco-friendliness and sustainability (Wu et al. 2009; Khalid et al. 2021). However, biological treatment methods are faced with inability to remove sludge, prolonged treatment time and need for extensive land area for

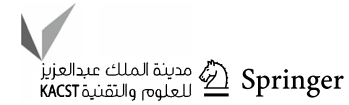


Table 2 Efficiencies of bioremediation in the removal of pollutants from oily wastewater

\begin{tabular}{|c|c|c|c|}
\hline Oily wastewater type & Inoculum & $\begin{array}{l}\text { Treatment effect (Removal effi- } \\
\text { ciency) }\end{array}$ & Reference \\
\hline Oilfield wastewater & $\begin{array}{l}\text { Polyammoniacum-immobilized } \\
\text { B350M and B350 }\end{array}$ & $\begin{array}{l}78 \% \text { TOC, } 94 \% \text { oil by B350M; } 64 \% \\
\text { TOC, } 86 \% \text { oil by B350 }\end{array}$ & Zhao et al. (2006) \\
\hline Oilfield-produced water & PVA-immobilized Bacillus sp. M-12 & $90 \% \mathrm{COD}$ & Li et al. (2005) \\
\hline Synthetic and carwash wastewaters & $\begin{array}{l}\text { Chitosan-immobilized Sphingobium } \\
\text { sp. P2 }\end{array}$ & $80-90 \%$ TPH, $73 \pm 11 \%$ COD & Khondee et al. (2012) \\
\hline Oily bilge water & $\begin{array}{l}\text { Polyurethane foam-immobilized } \\
\text { Gordonia sp. JC } 11\end{array}$ & $40-50 \%$ lubricant & Chanthamalee et al. (2013) \\
\hline Synthetic oily wastewater & $\begin{array}{l}\text { Polyethylene plastic pellet-immo- } \\
\text { bilized Pseudoxanthomanas sp. } \\
\text { RN } 402\end{array}$ & $\begin{array}{l}89 \% \text { diesel; } 83 \% \text { crude oil; } 92 \% \\
n \text {-tetradecane; } 65 \% \text {-hexadecane }\end{array}$ & Nopcharoenkul et al. (2013) \\
\hline Engine oil wastewater & Ochrobactrum sp. C1 & $57 \%$ oil & Bhattacharya et al. (2015) \\
\hline Synthetic oily wastewater & Pseudomonas sp. & $95 \pm 1.5 \%$ oil & Azhdarpoor et al. (2014) \\
\hline Olive oil mill processing wastewater & Yarrowia lipolytica ATCC 20,255 & $80 \%$ oil & De Felice et al. (2004) \\
\hline Olive mill wastewater & $\begin{array}{l}\text { Trichosporon cutaneum, Geotrichum } \\
\text { candidum }\end{array}$ & $\begin{array}{l}88 \% \text { COD, } 64 \% \text { phenolic com- } \\
\text { pounds by Trichosporon cutaneum; } \\
77 \% \text { COD, } 47 \% \text { color by Geotri- } \\
\text { chum candidum }\end{array}$ & Dragicevic et al. (2010) \\
\hline $\begin{array}{l}\text { Food processing wastewater, electric } \\
\text { and electronic industry wastewater } \\
\text { and POME }\end{array}$ & $\begin{array}{l}\text { Serratia marcescens EU555434, } \\
\text { Aeromonas hydrophila KF049214, } \\
\text { Bacillus cereus KJ605415 }\end{array}$ & $\begin{array}{l}91 \% \text { O\&G by Serratia marcescens; } \\
100 \% \text { O\&G by Bacillus cereus; } \\
100 \% \text { O\&G by Aeromonas } \\
\text { hydrophila }\end{array}$ & Affandi et al. (2014) \\
\hline
\end{tabular}

treatment processes (Chopra et al. 2011). The performance of biological methods in the removal of pollutants from oily wastewater is illustrated in Table 2 and discussed in detail below:

\section{Batch biodegradation of oily wastewater using single or consortium of microorganisms}

Batch biodegradation process offers an efficient approach at shorter hydraulic retention time (HRT) for the treatment of oily wastewater (Agamuthu 1995; Nzila et al. 2017). Oswal et al. (2002) used hydrocarbon-degrading Yarrowia lipolytica NCIM 3589 for the treatment of palm oil mill effluent (POME). Results indicated COD reduction of about $95 \%$ at short HRT of $2 \mathrm{~d}$. Similar results were reported by Karim and Kamil (1989) after 10-14-d degradation when using Trichoderma viride for the treatment of POME. Bhattacharya et al. (2015) investigated degradation of oil (waste engine oil and waste transformer oil)-contaminated site by an exotic Ochrobactrum sp. C1 isolated from steel plant effluent area in Burnpur, India. Degradation efficiencies of $48.5 \pm 0.5 \%$ (waste engine oil) and $30.47 \pm 0.25 \%$ (waste transformer oil) were recorded within $7 \mathrm{~d}$. Azhdarpoor et al. (2014) investigated the treatment of oily wastewater using Pseudomonas sp. isolated from compost fertilizer. Oil removal efficiency of over $95 \pm 1.5 \%$ was reported at a concentration below
$8.4 \mathrm{~g} / \mathrm{L}$. At oil concentration of $22 \mathrm{~g} / \mathrm{L}$, there was reduction $(85 \pm 2.5 \%)$ in oil removal efficiency at retention time of 44 h. De Felice et al. (2004) treated olive oil mill processing wastewater using Yarrowia lipolytica ATCC 20,255 under batch culture conditions. The yeast was capable of reducing COD by $80 \%$ in $24 \mathrm{~h}$.

Bioaugmentation with a consortium of microorganisms is an effective approach for the removal of pollutants present in oily wastewater (Corti-Monzón et al. 2020; Ke et al. 2021). Shokrollahzadeh et al. (2008) treated oily wastewater in an activated sludge inoculated with a consortium of microorganisms consisting of 67 bacterial strains from Acinetobacter, Pseudomonas, Comamonas, Flavobacterium, Cytophaga, Sphingomonas, Acidovorax, and Bacillus genera and one mold species, Trichoderma sp. Removal efficiencies $(80 \%, 92 \%, 99 \%$ and $89 \%)$ of total hydrocarbon, vinyl chloride, ethylene dichloride and COD, respectively, were reported. Bala et al. (2015) studied the reduction of organic load from palm oil mill effluent (POME) using mixed cultures of Micrococcus luteus 101 PB, Stenotrophomonas maltophila 102 PB, Bacillus cereus 103 PB, Providentia vermicola 104 PB, Klebsiella pneumoniae 105 PB and Bacillus subtilis $106 \mathrm{~PB}$. The consortia organisms, especially Bacillus cereus 103 PB and Bacillus subtilis 106 PB demonstrated highest COD (90.64\%) and BOD (93.11\%) reduction efficiencies. Affandi et al. (2014) studied the potential of O\&G-degrading bacteria: Serratia marcescens EU555434, Aeromonas hydrophila KF049214 and Bacillus cereus 
KJ605415 isolated from food processing and electrical and electronic industries as well as from POMEs, respectively, for the treatment of respective high-strength oily wastewater. Maximum O\&G degradation (91\%) was demonstrated by Serratia marcescens within $12 \mathrm{~d}$ of incubation at initial

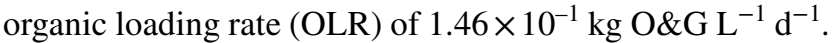
Bacillus cereus recorded 100\% of POME (3012 mg/L O\&G) degradation within $7 \mathrm{~d}$ of incubation. Similarly, Aeromonas hydrophila recorded $100 \%$ of O\&G $(4.88 \mathrm{mg} / \mathrm{L})$ degradation from electrical and electronic wastewater after 2-h incubation.

\section{Aerobic bioreactor technology for oily wastewater treatment}

Bioreactor technology is employed for the treatment of oily wastewater owing to its ability to permit steady and flexible operational conditions, high biomass retention times, tolerance to toxic and recalcitrant pollutants, high microbial growth and organic carbon oxidation rates as well as enhanced process performance (Hamoda and Al-Ghusain 1998; Galvez et al. 2003; Rodgers et al. 2003; Kuyukina et al. 2020). Vendramel et al. (2015) treated high-strength petroleum refinery wastewater using an aerobic submerged fixed-bed reactor. There was effective removal of COD (91\%), dissolved organic carbon (DOC) (90\%), TSS (92\%), ammonium (90\%), average polysaccharide/volatile attached solids $(6 \%)$ while proteins/volatile attached solids were found to be $6 \%$ and $50 \%$, respectively, within $250 \mathrm{~d}$ of experimental runs. Izanloo et al. (2007) treated crude oil-containing wastewater using an aerated submerged fixed-film reactor consisting of Bee-Cell 2000 as support media. Results indicated removal efficiencies of 70.87-93.12\% COD in the OLR ranged between 1.310 and $15.797 \mathrm{~g} \mathrm{COD} / \mathrm{m} /$ day. Xie et al. (2007) studied the treatment of moderately polluted wastewater from an oil refinery using a small-scale fixed film BAF process. Removal efficiencies of COD (84.5\%), oil pollutants (94\%) and SS (83.4\%) at effluent concentrations of $12.5 \mathrm{mg} / \mathrm{L}, 0.27 \mathrm{mg} / \mathrm{L}$ and $14.5 \mathrm{mg} / \mathrm{L}$ for COD, oil pollutants and SS, respectively, under optimal operating conditions of HRT $(1.0 \mathrm{~h})$, air/water volume flow ratio $(5: 1)$ and backwashing cycle (every 4-7 d) were reported.

Malakahmad et al. (2011) assessed the performance of a laboratory-scale sequencing batch reactor (SBR) for the treatment of synthetic oily wastewater rich in mercury and cadmium. Removal efficiencies of $88.3 \%$ and $97.4 \%$ were reported for mercury $(9.03 \pm 0.02 \mathrm{mg} / \mathrm{L})$ and cadmium $(15.52 \pm 0.02 \mathrm{mg} / \mathrm{L})$, respectively. This is similar to the findings of Hudson et al. (2001), where a COD removal of $93 \%$ was achieved at HRT of $53 \mathrm{~h}$. Chan et al. (2010) investigated aerobic treatment of POME using SBR. Performance of the SBR was assessed by measuring COD, BOD, TSS removal and sludge volume index. Results showed maximum COD (95-96\%), BOD (97-98\%) and TSS (98-99\%) removal efficiencies at optimum OLR, sludge loading rate and mixed liquor volatile suspended solid concentrations of $1.8-4.2 \mathrm{kgCOD} / \mathrm{m}^{3} \mathrm{~d}, 2.5-4.6 \mathrm{~kg} \mathrm{TSS} / \mathrm{m}^{3} \mathrm{~d}$ and $22,000-25,000 \mathrm{mg} / \mathrm{L}$, respectively.

\section{Bioreactors for oily wastewater treatment using immobilized microorganisms}

Immobilization of microorganisms in a suitable matrix is a very useful and alternative approach for the remediation of heavy oil-polluted wastewater (Adetunji and Olaniran 2018). It ameliorates wastewater treatment efficiency and further enhances recovery and reusability of the immobilized cells, hence reducing overall costs (Suryanti et al. 2017; Adetunji and Olaniran 2018). In addition, the support materials protect the organisms from harsh environmental conditions, including extreme pollutant concentrations and mechanical stress (Lee et al. 2017). This further increases survival rate and biodegradability of the immobilized cells when compared to free cells (Chavan and Mukherji 2008; Tyagi et al. 2011).

Pretreatment of oily wastewater by a couple of biological aerated filter (BAF) reactors run for $142 \mathrm{~d}$ at HRT of $4 \mathrm{~h}$ with a collection of immobilized microorganisms, B350M and B350 has been investigated (Zhao et al. 2006). The immobilized organisms were efficient in treating the organic compound-containing oily wastewater. Immobilized B350M had mean total organic carbon (TOC) and oil degradation potentials of $78 \%$ and $94 \%$, respectively, whereas B350 degraded TOC (64\%) and oil (86\%). In another study, removal of COD from oilfield-produced water was investigated using Bacillus sp. (M-12) immobilized on polyvinyl alcohol (PVA) (Li et al. 2005). Results indicated more than $90 \%$ COD removal efficiency at initial COD of $2600 \mathrm{mg} / \mathrm{L}$. Khondee et al. (2012) used airlift bioreactor comprising chitosan-immobilized Sphingobium sp. P2 for the treatment of lubricant-rich wastewater. Immobilized bacteria $(4 \mathrm{~g} / \mathrm{L})$ were effective in removing $85 \pm 5 \% \mathrm{TPH}$ and $73 \pm 11 \%$ COD from carwash wastewater containing $25-200 \mathrm{mg} / \mathrm{L}$ lubricant at HRT of $2 \mathrm{~h}$ within $70 \mathrm{~d}$. However, in a semicontinuous batch experiment, the immobilized bacteria had a removal efficiency of $80-90 \%$ of TPH $(200 \mathrm{mg} / \mathrm{L})$. Chanthamalee et al. (2013) treated oily bilge from small fishing vessels using polyurethane foam-immobilized Gordonia $\mathrm{sp}$. JC11. The immobilized bacteria were found to be effective in removing $40-50 \%$ of boat lubricant $(<1000 \mathrm{mg} / \mathrm{L})$. Nopcharoenkul et al. (2013) used immobilized Pseudoxanthomonas sp. RN402 for the degradation of diesel-, crude oil-, $n$-tetradecane- and $n$-hexadecane-contaminated sites.

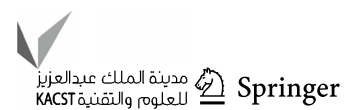


Effective removal of diesel (89\%), crude oil (83\%), $n$-tetradecane $(92 \%)$ and $n$-hexadecane $(65 \%)$ was recorded.

\section{Anaerobic bioreactors for oily wastewater treatment}

Bioremediation under anaerobic condition in a bioreactor is effective for treatment of high-strength oily wastewater (Mainardis et al. 2020). It saves energy required for aeration; converts pollutants into methane gas; requires low nutrients cost-effective; and produces less sludge \& biomass (Chowdhury et al. 2010). However, sludge flotation/ washout and adsorption of O\&G on the sludge surface may decrease the efficiency of anaerobic oily wastewater treatment (Rinzema et al. 1994; Hwu et al. 1996, 1998; Pereira et al. 2003; Shende and Pophali 2020).

Rastegar et al. (2011) employed up-flow anaerobic sludge blanket (UASB) bioreactor for the optimization of oily wastewater treatment. COD removal of $81 \%$ was achieved at HRT of $48 \mathrm{~h}$. The production of biogas increased as the HRT increases, yielding $559 \mathrm{ml} / \mathrm{h}$ at HRT of $40 \mathrm{~h}$ and COD (influent) of $1000 \mathrm{mg} / \mathrm{L}$. At optimum influent COD $(630 \mathrm{mg} / \mathrm{L})$, up-flow velocity $(0.27 \mathrm{~m} / \mathrm{h})$ and HRT (21.4 h), COD removal of $76.3 \%$ and biogas production of $0.25 \mathrm{~L} /$ feed were reported. Palenzuela-Rollon et al. (2002) investigated the performance of UASB for the treatment of mixed sardine and tuna canning effluent consisting of varying lipids contents. Results showed approximately $78 \pm 8 \%$ COD removal and $61 \pm 17 \%$ COD conversion to methane at OLR of $2.3 \mathrm{~g} \mathrm{COD} / \mathrm{L} . \mathrm{d}$ and HRT of $7.2 \pm 2.8 \mathrm{~h}$.

Up-flow anaerobic sludge fixed film (UASFF) reactor is an amalgamation of UASB reactor and immobilized cell or fixed film reactor. It is designed to curb challenges such as prolonged formation of granule sludge encountered by UASB reactor. Emadian et al. (2015) studied the treatment of low-strength bilge water obtained from Caspian Sea Ships using UASFF reactor under varying HRTs $(8 \mathrm{~h}$ and $10 \mathrm{~h})$ and OLR (0.12-0.6 g/COD/L.d). Results demonstrated removal efficiencies of 75\% (COD) and 99\% (TSS) at $\operatorname{HRT}(8 \mathrm{~h})$ and OLR $(0.6 \mathrm{~g} \mathrm{COD} / \mathrm{L} . \mathrm{d})$. In addition, a significant reduction in effluent oil concentration, found to be lower than the international maritime organization discharge limit standards (15 ppm), was reported. Lopez et al. (2014) studied anaerobic digestion of wastewater separated from grease trap waste in biochar packed up-flow column reactors. There was reduction in COD $(95 \%)$ coupled with increased methane headspace concentrations (60-80\%) along with conversion (90\%) of FOG to biodiesel.

Hybrid technology of different anaerobic systems in a bioreactor provides good process efficiency and stability. Treatment of heavy oily wastewater by a combination of UASB reactor and a two-stage BAF system has been investigated (Zou 2015). Removal of COD (90.2\%), ammonia nitrogen $(90.8 \%)$, oil $(86.5 \%)$ and polyaromatic hydrocarbons (PAHs) (89.4\%) was reported during 180-d study period. Liu et al. (2013) treated high-strength oily wastewater using a combination of UASB and immobilized BAFs. Results demonstrated removal of COD (74\%), ammonia nitrogen (94\%) and SS (98\%) during $252 \mathrm{~d}$ of operation. El-Goharyet al. (2009) investigated the efficacy of classical and hybrid UASB for anaerobic treatment of catalytically oxidized olive oil mill wastewater (OMW) collected from a local olive oil production factory in Egypt. Results indicated removal efficiencies of COD total $(83 \%), \mathrm{BOD}_{5 \text { total }}(84 \%)$, TOC $(81 \%)$, volatile fatty acid $(93 \%)$ and O \& G (81\%) at HRT of $48 \mathrm{~h}$ and OLR of $2.0 \mathrm{~kg} \mathrm{COD} / \mathrm{m}^{3}$. The hybrid UASB produced a better effluent quality when compared to classical type. This was due to the availability of packing curtain sponge which reduced SS washout in hybrid UASB.

\section{Membrane bioreactors (MBRs) for oily wastewater treatment}

Membrane bioreactor involves a combination of biological reactor and membrane technology for the effective removal of pollutants in oily wastewater (Fazal et al. 2015). It is an innovative and promising approach for wastewater treatment and reuse (Guo et al. 2008). It is simple, efficient and requires little space and modest technical support (DiGiano 2004; Sharghi et al. 2020). However, membrane fouling and high operational costs remain the ultimate challenges (Guo et al. 2008).

Soltani et al. (2010) used MBR to treat oily wastewater. Degradation of hydrocarbons, hexadecane and phenanthrene in the presence of salts at HRT of less than $15 \mathrm{~h}$ was as a result of activity of bacteria domiciled in the reactor. Pendashteh et al. (2012) investigated the effectiveness of a MBR in the treatment of oily wastewater. Results indicated a recovery of COD (97.5\%), TOC (97.2\%) and O\&G (98.9\%) from the wastewater. In contrast, the real produced water yielded COD (86.2\%), TOC (90.8\%) and O\&G (90\%). In addition, at peak total dissolved solids (TDS) (250, $000 \mathrm{mg} / \mathrm{L}$ ), a drastic reduction in COD removal from synthetic and real wastewaters by $90.4 \%$ and $17.7 \%$, respectively, was recorded.

Bienati et al. (2008) employed submerged MBR for the treatment of oily wastewater using microfiltration hollow fiber membranes. The oily wastewater had hydrocarbon and sludge concentrations of $600-1500 \mathrm{mg} / \mathrm{L}$ and $14-28 \mathrm{mg} / \mathrm{L}$, respectively. Significant oil removal $(<98 \%)$ at low HRT and high biomass concentration was reported. Yang et al. (2012) treated simulated restaurant wastewater by submerged MBR. Results demonstrated total COD removal efficiencies of 
$98.3 \%$ and $99.1 \%$ for low- and high-strength restaurant wastewater, respectively, at initial influent oil concentration of 5 and $100 \mathrm{mg} / \mathrm{L}$. Viero et al. (2008) used submerged MBR for the treatment of refinery wastewater. There was improvement in phenol removal efficiency ( $>98 \%$ ); COD and TOC removals were achieved at $17 \%$ and $20 \%$, respectively.

\section{Membrane technology for oily wastewater treatment}

Membranes are tinny layers of synthetic organic or inorganic materials used for selective separation of fluid from other constituents (Ahmadun et al. 2009). Membrane treatment process involves application of special porous material for the physical separation of pollutants present in the oily wastewater (Gryta 2020; Makisha 2020). It is increasingly being applied for the treatment of oil-contaminated wastewater, especially in highly stable oil-water emulsions with a satisfactory discharge quality (Elimelech and Phillip 2011; Awaleh and Soubaneh 2014; Karakulski and Gryta 2017) (Table 3). It requires no chemicals, less energy requirement, simple and easy to handle with organized process conduction (Padaki et al. 2015). It is a pressure-driven technique, categorized into ultrafiltration, microfiltration, nanofiltration and reverse osmosis, which are virtually identical processes, but differ based on the pore size of the membranes (Pendergast and Hoek 2011).

Membranes are made of three distinct materials including polymeric, ceramic and/or nano-materials occurring in hollow fiber, spiral and tubular structures for separation of oily wastewater (Zhu et al. 2014; Barambu et al. 2020). The removal efficiencies of various forms of membranes for oily wastewater treatment are discussed in detail below:

\section{Polymeric membranes}

Polymeric membranes are economical with small size, low energy requirements and high capacity to remove particles, emulsified and dispersed oil (Padaki et al. 2015; Hussain and
Al-Yaari 2021). However, they are ineffective to remove volatile substances and promote fouling easily leading to reduction in flux rate and weak separation during oily wastewater treatment (Padaki et al. 2015). They are made of special materials such as polyvinylidene fluoride (PVDF), polytetrafluorethylene (PTFE), polyamide (PA), polyethersulfone (PES), polysulfone (PSF) (Ochoa et al. 2003; Mansourizadeh and Azad 2014). Salahi et al. (2010) treated oily wastewater effluents obtained from Tehran refinery using thin film composite-PA-reverse osmosis membrane. Results indicated high removal of total dissolved solids (TDS) (87\%), COD $(95 \%), \mathrm{BOD}_{5}(95.3 \%)$, TOC $(90 \%)$, turbidity $(81.8 \%)$ and O\&G contents $(86.1 \%)$ in addition to total recovery of free oil, TSS and color at flow rate of $50 \mathrm{~L} / \mathrm{m}^{2} \mathrm{~h}$.

Improvement on the hydrophilicity and antifouling performance of polymeric membranes is achieved by combination with hydrophilic components (Hyun et al. 2006; Asatekin and Mayes 2009; Hashim et al. 2009) or surface modification (Shi et al. 2008; Sagle et al. 2009). Masuelli et al. (2012) synthesized charged PVDF membranes modified with glycidyl methacrylate and ethylene glycol dimethacrylate for the treatment of oily wastewater using ultrafiltration process. Oil emulsion rejection and COD removal efficiencies were $98 \%$ and $<59 \mathrm{mg} / \mathrm{L}$, respectively. The modified membranes demonstrated low fouling (less than 16.6\%). Shirazi et al. (2013) studied thermal modification of polystyrene electrospun membrane for the treatment of biodiesel water effluent. Results demonstrated reduction in COD (75\%), BOD (55\%), total solids (TS) (92\%), TDS $(96 \%)$ and TSS $(30 \%)$ of the treated effluent.

\section{Ceramic membranes}

Ceramic membranes are resistant to harsh environmental conditions due to high thermal, chemical and mechanical stabilities in addition to resistance to high oil content concentration and strong cleaning agents (Benfer et al. 2001; Faibish and Cohen 2001; Yoshino et al. 2005; Padaki et al. 2015; Tomczak and Gryta 2021). However, because of pore

Table 3 Efficiencies of membrane technology in the removal of pollutants from oily wastewater

\begin{tabular}{lll}
\hline Oily wastewater type & Treatment effect & Reference \\
\hline Synthetic oil- water emulsions & $98.8 \%$ O \& G & Nandi et al. (2010) \\
Oil-water emulsion from a crude oil refinery, India & $93 \%$ oil & Mittal et al. (2011) \\
Raw oily wastewater from Tehran refinery, Iran & $85 \%$ O\& G; 100\% TSS; 98.6\% turbidity and > 95\% TOC & Abadi et al. (2011) \\
Raw oily wastewater from Tehran refinery & $31.6 \%$ TDS; 96.4\% turbidity; 94.1\% TSS and 97.2\% O\&G & Salahi et al. (2010) \\
Synthetic oil-water emulsion & $>98 \%$ oil; <59 mg/L COD & Masuelli et al. (2012) \\
Biodiesel water effluent & $75 \%$ COD; 55\% BOD; 92\% TS; 96\% TDS and 30\% TSS & Shirazi et al. (2013) \\
Wastewater from oil refinery, Tehran & $78.1 \%$ COD and 90.4\% TOC & Sarfaz et al. (2012) \\
\hline & &
\end{tabular}


size constraint, direct application of ceramic membranes for treatment of oily wastewater results in fouling and low fluxes (Hua et al. 2007; Vasanth et al. 2011).

The development of low-cost and high-performance ceramic membranes for the treatment of oily wastewater has been investigated (Parma and Chowdhury 2014). The membranes were suitable for oil removal yielding a maximum separation of $53 \%$. Nandi et al. (2010) used low cost ceramic microfiltration membrane made from inorganic precursors (sodium carbonate, boric acid, kaolin, quartz, feldspar and sodium metasilicate) with varying trans-membrane pressures (TMPs) $(68.95-275.8 \mathrm{kPa})$ to treat synthetic oily wastewater consisting of 125 and $250 \mathrm{mg} / \mathrm{L}$ oil concentrations. The membrane demonstrated $98.8 \%$ oil rejection efficiency and $5.36 \times 10^{-6} \mathrm{~m}^{3} / \mathrm{m}^{2} \mathrm{~s}$ permeate flux after $60 \mathrm{~min}$ at $68.95 \mathrm{kPaTMP}$. Mittal et al. (2011) synthesized low-cost hydrophilic ceramic-polymeric composite membrane from clay, kaolin and small amount of binding materials for the treatment of oily wastewater. The porosity and effective pore size of the membrane stretched between 0.56 and $28 \mathrm{~nm}$ and were used for the treatment of oily wastewater containing 50-200 mg/L oil. Maximum oil removal efficiency (93\%) was achieved at initial oil concentration of $200 \mathrm{mg} / \mathrm{L}$ and TMP of $138 \mathrm{kPa}$

Materials such as alumina, silica, zirconia and titania are used for modification of ceramic filtration membranes (Padaki et al. 2015). Among these, zirconia-ceramic filtration membranes are more effective for the treatment of oily wastewater (Zhu et al. 2014). Zhou et al. (2008) reduced membrane fouling by coating $\mathrm{Al}_{2} \mathrm{O}_{3}$-microfiltration ceramic membrane with nano-sized $\mathrm{ZrO}_{2}$. Their results demonstrated an improvement in the hydrophilic properties of the membrane. A steady flux of $88 \%$ and oil rejection of $97.8 \%$ was reported by using stable $1 \mathrm{~g} / \mathrm{L} 20^{\#}$ engine oil-water emulsion as a feed.

\section{Nanomaterial-based membranes}

Nanomaterial-based membranes are made of nanofibrous films with thin separation layer for effective treatment of oily wastewater (Jain et al. 2021). They possess high surface area, high flux rate and high rejection rate when compared with conventional filtration membranes (Zhu et al. 2014). Sarfaraz et al. (2012) investigated the potential of nanoporous membrane-powdered activated carbon (NPMPAC) for the treatment of oily wastewater. An increase in permeation flux $\left(133.8 \mathrm{~L} /\left(\mathrm{m}^{2} \mathrm{~h}\right)\right.$ with the removal of COD $(78.1 \%)$ and TOC (90.4\%) as well as decrease in steady fouling resistance $(46.1 \%$ ) was reported. The hybrid NPM-PAC improved the efficiency of NPM, membrane fouling and permeation flux. Salahi et al. (2013) studied the treatment of oily wastewater collected from desalter plant using modified
NPM. Maximum permeation flux of $180.1 \mathrm{~L} \mathrm{~m}^{-2} \mathrm{~h}^{-1}$ was obtained when the feed temperature, TMP, $\mathrm{CFV}, \mathrm{pH}$ and salt concentration were $45^{\circ} \mathrm{C}, 3$ bar, $1.3 \mathrm{~m} / \mathrm{s}, 10$ and $11.2 \mathrm{~g} / \mathrm{L}$, respectively. The membrane was effective in removal of TSS (100\%), TDS (44.4\%), O\&G contents (99.9\%), COD $(80.3 \%)$ and BOD $(76.3 \%)$.

\section{Electrochemical technology for oily wastewater treatment}

Electrochemical technology is a promising alternative for the treatment of oily wastewater containing organic pollutants by the application of electric current supplied to the electrodes (de Almeida et al. 2014; Treviño-Roséndez et al. 2021). It occurs as electrocoagulation (EC), electrofloatation (EF), etc. (Chen 2004). It possesses advantages such as environmental compatibility, versatility, energy efficiency, safety, selectivity, amenability to automation and cost-effectiveness (Bayramoglu et al. 2006; de Almeida et al. 2014). Operating conditions such as $\mathrm{pH}$, operating time, current density, initial phenol concentration, $\mathrm{NaCl}$ addition, temperature, electrode materials and phenol structure affect the performance of electrochemical treatment processes (El-Ashtoukhy et al. 2013; de Almeida et al. 2014). Table 4 illustrates the efficiencies of electrochemical techniques in the removal of pollutants from oily wastewater. The various forms of electrochemical treatment technologies and their potentials for oily wastewater remediation are discussed in detail below:

\section{Electrocoagulation treatment technology}

Electrocoagulation (EC) is a technology that involves the release of coagulant in situ by the electrolytic dissolution of metal ions from metal electrode following application of electric current, resulting in simultaneous formation of hydroxyl ions and hydrogen gas production (Chen et al. 2004; Cerqueira et al. 2014; Tetteh and Rathilal 2020). The coagulants aggregate and precipitate SS with a simultaneous adsorption of dissolved pollutants (Chaturvedi 2013). Tiny bubbles of hydrogen and oxygen gas released from the electrodes collide with air bubbles to float the pollutant particles (Chaturvedi 2013). It requires no chemical (except for $\mathrm{pH}$ control); tolerate broad range of pollutants and fluctuation in influent quality; reduced residue; fully automated with less operator attention; lower sludge volume and better sludge quality (Kumar et al. 2004; Merma et al. 2020). However, high capital and energy costs formed crucial barriers to industrial application of EC, despite its high effectiveness and environmental friendliness (Gu et al. 2009; UludagDemirer et al. 2020). 
Table 4 Efficiencies of electrochemical technology in the removal of pollutants from oily wastewater

\begin{tabular}{|c|c|c|c|}
\hline Oily wastewater type & Operation condition & Treatment effect & Reference \\
\hline Refinery oil wastewater & $\begin{array}{l}\text { Current density } 23.6 \mathrm{~mA} / \mathrm{cm}^{2} \text {; } \\
\text { time } 120 \mathrm{~min}\end{array}$ & $97 \%$ phenol & Abdelwahab et al. (2009) \\
\hline Petroleum refinery wastewater & $\begin{array}{l}\text { Current density } 9 \mathrm{~mA} / \mathrm{cm}^{2}, \mathrm{pH} \\
8.0 \text {, time } 4 \mathrm{~min}\end{array}$ & $87 \%$ COD; $90 \%$ TSS & Ibrahim et al. (2013) \\
\hline $\begin{array}{l}\text { Petroleum-contaminated waste- } \\
\text { water }\end{array}$ & $\begin{array}{l}\text { Current density } 18 \mathrm{~mA} / \mathrm{cm}^{2}, \mathrm{pH} \\
7.0\end{array}$ & $95 \% \mathrm{TPH}$ & Moussavi et al. (2011) \\
\hline Oily bilge wastewater & $\begin{array}{l}\text { Current density } 1.5 \mathrm{~mA} / \mathrm{cm}^{2} \text {, } \\
60-90 \mathrm{~min}\end{array}$ & $\begin{array}{c}93 \pm 3.3 \% \text { BOD; } 78.1 \pm 0.1 \% \\
\text { COD, } 95.6 \pm 0.2 \% \text { O\&G }\end{array}$ & Asselin et al. (2008) \\
\hline Petrochemical wastewater & $\begin{array}{l}\text { Current density } 21.64 \mathrm{~mA} / \mathrm{cm}^{2} \text {, } \\
\mathrm{NaCl} \text { concentration } 2 \mathrm{~g} / \mathrm{L} \text {, } \\
30 \mathrm{~min}\end{array}$ & $97.43 \%$ turbidity & Giwa et al. (2012) \\
\hline Oily bilge wastewater & $\begin{array}{l}\text { Current density } 12.8 \mathrm{~mA} / \mathrm{cm}^{2} \text {, } \\
\text { reaction temperature } 32{ }^{\circ} \mathrm{C}\end{array}$ & $\begin{array}{l}99.2 \% \mathrm{COD} ; 93.2 \% \text { O\&G; } 91.1 \% \\
\text { turbidity }\end{array}$ & Korbahti and Artut (2010) \\
\hline Biodiesel wastewater & $\begin{array}{l}\text { Current density } 8.32 \mathrm{~mA} / \mathrm{cm}^{2}, \mathrm{pH} \\
6.0,25 \mathrm{~min}\end{array}$ & $\begin{array}{l}97.8 \% \text { O\&G; } 96.9 \% \text { SS; } 55.4 \% \\
\text { COD }\end{array}$ & Srirangsan et al. (2009) \\
\hline Raw oily wastewater & $\begin{array}{l}\text { Current density } 12-16 \mathrm{~mA} / \mathrm{cm}^{2} \text {, } \\
5-20 \mathrm{~min}\end{array}$ & $\begin{array}{l}98.8 \% \mathrm{SS} ; 90 \% \mathrm{COD} ;>80 \% \mathrm{O} \\
\quad \& \mathrm{G}\end{array}$ & Sekman et al. (2011) \\
\hline Biodiesel wastewater & $\begin{array}{l}\text { Applied voltage } 18.2 \mathrm{~V}, \mathrm{pH} 6.06 \text {, } \\
23.5 \mathrm{~min}\end{array}$ & $\begin{array}{l}55.43 \% \text { COD; } 98.42 \% \text { O\&G; } \\
\text { 96.59\% SS }\end{array}$ & Chavalparit and Ongwandee (2009) \\
\hline Oily bilge wastewater & $\begin{array}{l}\text { Current density } 9.87 \mathrm{~mA} / \mathrm{cm}^{2} \text {, } \\
\text { inlet temperature } 29^{\circ} \mathrm{C}, 13 \mathrm{~min}\end{array}$ & 90.3\% COD; $81.7 \%$ O\&G & Ulucan et al. (2014) \\
\hline Synthetic oil-water emulsion & $\begin{array}{l}\text { Current density } 25 \mathrm{~mA} / \\
\mathrm{cm}^{2},<22 \mathrm{~min}\end{array}$ & $90 \%$ COD & Tir and Moulai-Mostefa (2008) \\
\hline Industrial oily wastewater & $\begin{array}{l}\text { Current density } 19.40 \mathrm{~mA} / \mathrm{cm}^{2} \text {, } \\
\text { energy consumption } 0.167 \\
\text { KWhm }^{-3}\end{array}$ & $99.71 \%$ oil & Nahui et al. (2008) \\
\hline
\end{tabular}

Investigation on the removal of organic pollutants from oily wastewater by EC has been reported (Abdelwahab et al. 2009). Abdelwahab et al. (2009) employed EC process to remove phenol from oil refinery wastewater using aluminum electrodes. Results showed phenol removal efficiency of $97 \%$ at high current density and solution pH 7.0 after $2 \mathrm{~h}$. There was an increase in EC rate as the phenol concentration decreases, with maximum removal rate attained at $30 \mathrm{mg} / \mathrm{L}$. Ibrahim et al. (2013) treated petroleum refinery wastewater by EC using mild steel and aluminum electrodes. Optimum COD and TSS removal of $87 \%$ and $90 \%$, respectively, under operating conditions of an initial $\mathrm{pH} 8.0$, current density $9 \mathrm{~mA} / \mathrm{cm}^{2}$ within $40 \mathrm{~min}$ of treatment was reported. Asselin et al. (2008) studied the treatment of oily bilge water by EC using iron and aluminum electrodes arranged in a bipolar or monopolar manner in an electrolytic cell. Results demonstrated removal of BOD $(93.0 \pm 3.3 \%)$, COD $(78.1 \pm 0.1 \%)$ and $\mathrm{O} \& \mathrm{G}(95.6 \pm 0.2 \%)$ under optimum operating conditions of 1.5 A within 60-90 min treatment period. Sekman et al. (2011) treated oily wastewater obtained from port waste reception facilities by EC using aluminum electrodes. Removal of SS (98.8\%) and COD (90\%) was reported at current density and electrolysis time of $16 \mathrm{~mA} / \mathrm{cm}^{2} \& 5 \mathrm{~min}$ and $12 \mathrm{~mA} / \mathrm{cm}^{2} \& 20 \mathrm{~min}$, respectively.
For effective and optimum performance of EC process, optimization of various operating parameters becomes necessary. Chavalparit and Ongwandee (2009) studied the optimization of EC process for the treatment of biodiesel wastewater using response surface methodology (RSM). The influence of initial $\mathrm{pH}$, applied voltage and reaction time on the removal of COD, O\&G and SS was further investigated using one factor at a time experiment. At optimum $\mathrm{pH}$ of 6.06 , applied voltage of $18.2 \mathrm{~V}$ and reaction time of $23.5 \mathrm{~min}$, removal of COD, O\&G and SS was reported at $55.43 \%, 98.42 \%$ and $96.59 \%$, respectively. Ulucan et al. (2014) optimized treatment of bilge water by EC process using RSM. Results showed optimum COD (90.3\%) and O\&G $(81.7 \%)$ removals at current density $9.87 \mathrm{~mA} / \mathrm{cm}^{2}$, inlet temperature $29{ }^{\circ} \mathrm{C}$ within $13 \mathrm{~min}$ of electrolysis. Srirangsan et al. (2009) studied optimum conditions for the treatment of biodiesel wastewater using EC process. Influence of current density, retention time, initial $\mathrm{pH}$ and electrode type ( $\mathrm{Fe}-\mathrm{Fe}, \mathrm{Fe}-\mathrm{C}, \mathrm{Al}-\mathrm{Al}, \mathrm{Al}-\mathrm{C}$ and $\mathrm{C}-\mathrm{C}$ ) was investigated on the treatment process. Results indicated optimum removal efficiencies of $97.8 \%$ (O\&G), $96.9 \%$ (SS) and $55.4 \%$ (COD) when using Al-C electrodes at current density of $8.32 \mathrm{~mA} / \mathrm{cm}^{2}$ and initial $\mathrm{pH}$ of 6.0 for $25 \mathrm{~min}$. 


\section{Electroflotation treatment technology}

Electroflotation (EF) is a process that allows pollutants to float on water body surface following electrolytic generation of tiny bubbles of hydrogen and oxygen gases from electrodes (Burns et al. 1997). The gas bubbles maintain contact with the pollutants to form a complex, which rises up to the water surface, leading to the removal of the pollutants by skimming (Hosny 1992). It differs from other flotation techniques such as dissolved air flotation in that it requires low operation costs, small land space requirement along with generation of uniform and finely dispersed gas bubbles (Ibrahim et al. 2001). The pollutant removal efficiency is dependent on solution $\mathrm{pH}$, current density, temperature, etc. (Ibrahim et al. 2001; Mota et al. 2015).

Studies on the removal of oil from oily effluents obtained from North Gujarat fields in India by EF process using aluminum electrodes have been carried out (Tiwari and Patel 2011). Results obtained demonstrated oil removal of $90.7 \%$ and $97.9 \%$ at $\mathrm{pH} 4.54$ and 9.5 , respectively, within $40 \mathrm{~min}$ flotation time at initial oil concentration of $145 \mathrm{mg} / \mathrm{L}$. Nahui et al. (2008) studied the treatment of industrial oily wastewater by EF using stainless steel and dimensionally stable anode electrodes with nominal compositions of Ti/ $\mathrm{Ru}_{0.34} \mathrm{Ti}_{0.66} \mathrm{O}_{2}$. Results indicated removal of $99.71 \%$ oil from $1050 \mathrm{ppm}$ of emulsified oil feed at current density of $19.40 \mathrm{~mA} / \mathrm{cm}^{2}$ and energy consumption of $0.167 \mathrm{kWhm}^{-3}$.

\section{Advanced oxidation processes (AOPs) for oily wastewater treatment}

Due to the presence of numerous toxic pollutants which cannot be treated by conventional methods, development of AOPs forms recent improvements in the treatment of oily wastewater (Ding et al. 1996; Lin et al. 2001; GarridoCardenas et al. 2020). These include electro-oxidation (EO) (Yavuz et al. 2010), Fenton oxidation (Brillaset al. 2009), photocatalytic oxidation (Chong et al. 2010), etc.

\section{Electrooxidation treatment technology}

Electrochemical oxidation (EO) is a complex phenomenon that involves generation of oxidants, which oxidize the pollutants present in oily wastewater, following application of electric current (Chen 2004; Abou-Taleb et al. 2020). The oxidation of pollutants occurs in two pathways: direct (anodic) and indirect oxidation. Direct oxidation occurs when the pollutants are directly oxidized on the surface of electrodes, and is influenced by electrode activity, pollutant diffusion rate and current density (Deng and Zhao 2015). In the case of indirect oxidation, it occurs with the aid of oxidizing agents generated electrochemically and is affected by $\mathrm{pH}$, temperature and rate of diffusion of generating oxidants (Chen 2004; Ochando-Pulido et al. 2015).

Gargouri et al. (2014) compared the efficacy of two different electrodes: $\mathrm{PbO}_{2}$ reinforced on tantalum $\left(\mathrm{Ta} / \mathrm{PbO}_{2}\right)$ and boron-doped diamond (BDD) anodes contained in an electrolytic batch cell, operated at different current densities $\left(30,50\right.$ and $\left.100 \mathrm{~mA} / \mathrm{cm}^{2}\right)$ for the treatment of oily wastewater. Results demonstrated COD removal efficiencies of $85 \%$ and $96 \%$ after $11 \mathrm{~h}$ and $96 \%$ after $7 \mathrm{~h}$, when using $\mathrm{PbO}_{2}$ and BDD, respectively. In addition, BDD was more efficient with higher oxidation rate and consumes less energy for removal of petroleum hydrocarbons from the produced water when compared with $\mathrm{PbO}_{2}$. Wei et al. (2010) studied the pretreatment processes for the removal of organic pollutants present in heavy oil refinery wastewater using a threedimensional electrode reactor. Removal efficiencies of COD (45.5\%), TOC (43.3\%) and toxicity $(67.2 \%)$ were recorded. Tran et al. (2009) investigated the removal of PAHs from creosote solution by $\mathrm{EO}$ using $\mathrm{RuO}_{2} / \mathrm{Ti}$ electrodes. Results showed removal of $80 \%$ PAHs after 90 min of electrolysis and at current density of $9.2 \mathrm{~mA} / \mathrm{cm}^{2}$. High degradation of PAHs was reported at original $\mathrm{pH}$ 6.0. Yavuz and Koparal (2006) removed phenol from a petroleum refinery wastewater by EO using ruthenium mixed metal oxide coated titanium electrodes. Results showed removal of phenol (94.5\%) and COD (70.1\%) at current density of $20 \mathrm{~mA} / \mathrm{cm}^{2}$.

\section{Electro-Fenton treatment technology}

Electro-Fenton is a novel chemical oxidation method, yet to receive much attention for the treatment of oily wastewater (Lin and Chen 1997; Sani et al. 2020). It is a combination of electrochemical process and Fenton oxidation and is based on the generation of oxidant $\left(\mathrm{H}_{2} \mathrm{O}_{2}\right)$ from cathode and ferrous ions from iron-containing acidic solution (Ahmed et al. 2021). The reaction of ferrous ion with $\mathrm{H}_{2} \mathrm{O}_{2}$ formed strong oxidant hydroxyl radicals, known as Fenton reagents, which caused degradation of non-biodegradable and toxic pollutants in oily wastewater by direct or indirect anodic oxidation through the formation of oxidants such as hydroxyl radicals and larger coagulants that enhance flocculation of organic matter (Panizza et al. 2000; Chen et al. 2002; Kusvuran et al. 2004; Kakavandi et al. 2019). Electro-Fenton technology is versatile, automated and eco-friendly with enhanced efficiency for energy (Sani et al. 2020). However, electro-Fenton technique is confronted with limitations such as insufficient production of $\mathrm{H}_{2} \mathrm{O}_{2}$, high resistivity and hindered current density (Sirés et al. 2014).

Studies on the application of electro-Fenton and ambient Fenton processes in the treatment of POME have been 
reported (Lim et al. 2017). Maximum COD removal efficiencies of $94 \%$ and $48 \%$, respectively, were recorded. The higher COD removal efficiency of electro-Fenton indicated its effectiveness in the removal of pollutants from the waste effluent. Similarly, electro-Fenton process was employed for the remediation of organic pollutants (recalcitrant) from landfill leachate at optimized conditions: $\mathrm{pH} 3.0, \mathrm{H}_{2} \mathrm{O}_{2} / \mathrm{Fe}^{2+}$ (1:1), current density $49 \mathrm{~mA} / \mathrm{cm}^{2}$ and reaction time $43 \mathrm{~min}$ ). Maximum COD and color removal efficiencies of $94 \%$ and 96\%, respectively, were recorded (Mohajeri et al. 2010).

Combination of electro-Fenton and EC has been applied for the treatment of petroleum refinery wastewater using iron electrodes (Yavuz et al. 2010). It was reported that electro-Fenton and EC processes removed $98.74 \%$ phenol and $75.71 \%$ COD at 6 and 9 min, respectively. Ulucan and Kurt (2015) treated bilge water obtained from Haydarpasa waste receiving facilities by a combination of EC, EF and electroFenton processes. Treatability of bilge water by EC-EF process was done using aluminum and iron electrodes. Comparison of aluminum and iron electrodes in EC-EF showed COD and O\&G removal efficiencies of $64.8 \%$ and $57 \%$, respectively, from aluminum and $36.2 \%$ and $12.5 \%$, respectively, from iron. However, higher COD and O\&G removal efficiencies of $71 \%$ and $69 \%$, respectively, were reported by electro-Fenton process.

\section{Photocatalytic oxidation technology}

Photocatalytic oxidation is widely used because of its superb pollutants' removal efficiency, low cost, photochemical stability and does not require toxic chemicals (Hoffmann et al. 1995; Saien and Nejati 2007; Chong et al. 2010; Lin et al. 2020). It requires the use of catalysts such as ultraviolet light, solar irradiation and $\mathrm{TiO}_{2}$. However, $\mathrm{TiO}_{2}$ is mostly preferred due to its stability in wastewater under broad environmental conditions (Zhang et al. 2012; Tetteh et al. 2020). Reactive oxygen species (hydroxyl radicals and superoxide radical anion) produced from the surface of catalysts (e.g. $\mathrm{TiO}_{2}$ ) under light irradiation is responsible for the degradation of organic pollutants present in wastewater (Sioi et al. 2006; Kuwahara et al. 2010).

Various factors such as catalyst dosage, $\mathrm{pH}$, temperature, light wavelength, intensity and salt and target contaminants concentrations affect photocatalysis in oily wastewater treatment (Ahmed and Haider 2018; Sundar and Kanmani 2020). Kang et al. (2011) investigated the influence of irradiation time, $\mathrm{pH}$, dissolved oxygen (DO), $\mathrm{TiO}_{2}$ dosage and initial $\mathrm{COD}$ concentration on the performance of vaccum $\mathrm{UV} / \mathrm{TiO}_{2}$ oxidation systems for the pretreatment of oily wastewater. Results demonstrated reduction in $\mathrm{COD}, \mathrm{BOD}_{5}$ and oil by $50 \pm 3 \%, 37 \pm 2 \%$ and $86 \pm 3 \%$, respectively, when using vaccum UV and $63 \pm 3 \%, 43 \pm 2 \%$ and $70 \pm 3 \%$, respectively, when using $\mathrm{TiO}_{2}$, under optimum operating conditions of irradiation $10 \mathrm{~min}$, initial COD $3981 \mathrm{mg} / \mathrm{L}, \mathrm{TiO}_{2} 150 \mathrm{mg} / \mathrm{L}$, pH 7.0 and flow rate of air $40 \mathrm{~L} / \mathrm{h}$. Mansouri et al. (2014) prepared polyethyleneimine/titania $\left(\mathrm{TiO}_{2}\right)$ multilayer film fabricated by a layer-by-layer self- assembly method for the treatment of raw petroleum refinery wastewater under UV light irradiation in three annular photocatalytic reactors. Maximum COD removal (98\%) was achieved at optimum initial COD concentration $200 \mathrm{mg} / \mathrm{L}, \mathrm{H}_{2} \mathrm{O}_{2}$ concentration $8.8 \mathrm{mM}, \mathrm{pH} 6.0$ and reaction time of $120 \mathrm{~min}$.

\section{Adsorption treatment technology}

Adsorption is a physical, chemical and electrostatic adhesion of pollutants onto surfaces (Wahi et al. 2013). The substance that is being removed from liquid phase at interphase is known as adsorbate, while the solid, liquid or gas phase onto which the adsorbate accumulates is called adsorbent (Razali et al. 2010). The most commonly used adsorbents include activated carbon, chitosan (Eldin et al. 2017; Doshi et al. 2018), alum, zeolite (Razali et al. 2010), polypropylene, activated bentonite (Al-Shahrani 2014), laterite (Hebbar and Jayantha 2013, 2014) and biosorbents (e.g. raw barley straw) (Ibrahim et al. 2012; Ramli and Ghazi 2020). Adsorption process is one of the effective techniques for removal of organic or inorganic pollutants present in oily wastewater (Yousef et al. 2020) (Table 5). It is mostly preferred due to
Table 5 Efficiencies of adsorption method in the removal of pollutants from oily wastewater

\begin{tabular}{|c|c|c|c|}
\hline Oily wastewater type & Adsorbent & Treatment effect & Reference \\
\hline Vegetable oil mill effluent & Crab shell chitosan & $\begin{array}{l}\text { 74\% COD; } 70 \% \text { TSS; } \\
56 \% \text { EC; } 92 \% \text { turbidity }\end{array}$ & Devi et al. (2012) \\
\hline Synthetic oily wastewater & Barley straw & $90 \%$ oil & Ibrahim et al. (2012) \\
\hline Palm oil mill effluent & Chitosan & $99 \%$ residual oil & Ahmad et al. (2005c) \\
\hline Palm oil mill effluent & Synthetic rubber powder & $88 \%$ residual oil & Ahmad et al. (2005a) \\
\hline Palm oil mill effluent & Oil palm waste & $83.74 \%$ oil & Jahi et al. (2015) \\
\hline Oil-water emulsion & $\begin{array}{l}\text { Zeolite, diatomite, benton- } \\
\text { ite, natural soil }\end{array}$ & $90 \% \mathrm{COD}$ & Yuan et al. (2011) \\
\hline
\end{tabular}


its direct application, simplicity and low processing costs (Ahmad et al. 2005a,b \& c; Sokker et al. 2011; Izevbekhai et al. 2020).

Application of natural biosorbents for the removal of pollutant load in oily wastewater has been studied (Ibrahim et al. 2010; Jun et al. 2020). Devi et al. (2012) employed low molecular weight crab shell chitosan as adsorbent for the treatment of vegetable oil mill effluent. Maximum removal of COD, TSS, electrical conductivity and turbidity was reported at $74 \%, 70 \%, 56 \%$ and $92 \%$, respectively. In addition, batch adsorption tests for the treatment of oily wastewater using surfactant-modified barley straw (biosorbent) have also been studied (Ibrahim et al. 2012). Maximum oil removal of above $90 \%$ was achieved.

Comparative studies of adsorption capacity of different adsorbents for the treatment of oily wastewater have been carried out (Razali et al. 2010). Zhou et al. (2008) compared the efficiency of cetyltrimethyl-ammonium bromide-modified polystyrene resin (R-CTAB) with granular-activated carbon (GAC) and polypropylene (PP) granular for the treatment of emulsified oily wastewater. Among the different absorbent materials, R-CTAB had the best oil removal efficiency. In addition, hybrid of R-CTAB and GAC removed more than $90 \%$ oil from the oily wastewater. Jahi et al. (2015) employed oil palm waste (oil palm leaves and oil palm frond) modified with lauric acid solution as adsorbent for the treatment of POME. The modified oil palm leaves had higher adsorption capacity with percentage oil removal of $83.74 \%$ when compared with modified oil palm frond with adsorption capacity of $39.84 \%$.

The influence of operating conditions such as adsorbent dosage and $\mathrm{pH}$ on the adsorption of oil from oily wastewater has been studied (Ahmad et al. 2005a; Cai et al. 2019). Yuan et al. (2011) investigated the demulsification of emulsified wastewater collected from steel and medical industries using artificial and natural zeolites, diatomite, bentonite and natural soil. Their results showed over $90 \%$ COD removal by the adsorbents at $60^{\circ} \mathrm{C}$ and $\mathrm{pH} 1.0$. Okiel et al. (2011) examined the removal of oil from oil-water emulsion by adsorption onto PAC, bentonite and deposited carbon while at the same time investigating the influence of adsorbent dosage $(0.1,0.3,0.5,0.7,1.0$ and $1.5 \mathrm{~g})$, contact time $(0.5-4 \mathrm{~h})$, adsorbent weight $(0.1-0.5 \mathrm{~g})$ and adsorbate concentrations (836, 1012, 1210 and 1613 ppm). Results indicated increase in percentage oil removal as the contact time and adsorbent weights increase and decrease in oil removal as the adsorbate concentration increases.

\section{Combined treatment technologies}

Owing to the complexity (in terms of composition) of oily wastewater coupled with inability of single technology to remediate free-floating, emulsified or dispersed oil from high-strength oil-contaminated wastewater, combined technologies are recently employed for efficient removal of hazardous pollutants from the wastewater (Han et al. 2020). It involves integration of assortment of treatment technologies for effective remediation of oily wastewater (Yu et al. 2017) (Table 6). This is notable of a cocktail application of EC and a fixed film aerobic bioreactor for the treatment of high-strength petroleum refinery wastewater at optimized conditions of $0.1 \mathrm{M} \mathrm{NaCl}, 6.5 \mathrm{~V}$ and 4 electrodes without prior $\mathrm{pH}$ adjustment. Maximum removal efficiencies of COD $(>88 \%)$ and TPH $(>80 \%)$ were recorded coupled with enhanced biodegradability of the wastewater (BOD/COD value: $0.015-0.5)$. Further treatment of the wastewater using immobilized cells in a bioreactor resulted in overall removal of COD (85\%) and TPH (98\%) within 30-d incubation (Pérez et al. 2016). In another study, Moslehyani et al. (2015, 2016a, b) investigated the applicability of a combination of photocatalytic reactor and ultrafiltration membrane for the

Table 6 Efficiencies of combined technologies in the removal of pollutants from oily wastewater

\begin{tabular}{|c|c|c|c|}
\hline Oily wastewater type & Combined technology & Removal efficiency & Reference \\
\hline Petroleum refinery wastewater & $\mathrm{EC}$ and fixed film aerobic bioreactor & $\begin{array}{l}>88 \% \text { COD and }>80 \% \mathrm{TPH} ; 95 \% \\
\text { COD and } 98 \% \mathrm{TPH} \text { (after bioreac- } \\
\text { tor treatment) }\end{array}$ & Pérez et al. (2016) \\
\hline Oilfield produced water & Reverse osmosis and adsorption & $92 \%$ TOC & Kwon et al. (2008) \\
\hline Oilfield produced water & $\begin{array}{l}\text { Membrane (SBR) and Membrane } \\
\text { (SBR)/reverse osmosis }\end{array}$ & $\begin{array}{l}\text { 90.9\% COD; } 92 \% \text { TOC; } 91.5 \% \text { O } \\
\quad \& \mathrm{G}\end{array}$ & Fakhru'l-Razi et al. (2010) \\
\hline Bilge wastewater & EC and nanofiltration & $\begin{array}{l}52 \% \text { COD; } 74 \% \text { COD (after EC- } \\
\text { nanofiltration process) }\end{array}$ & Akarsu et al. (2016) \\
\hline Oily bilge wastewater & $\begin{array}{l}\text { Photocatalytic reactor and ultrafiltra- } \\
\text { tion }\end{array}$ & $\begin{array}{l}>90 \% \text { hydrocarbon, }>80 \% \text { TOC } \\
\text { (after photocatalysis); }>99 \% \\
\text { hydrocarbon (after ultrafiltration) }\end{array}$ & Moslehyani et al. (2015; 2016a, b) \\
\hline Oily bilge wastewater & $\begin{array}{l}\text { Photocatalytic oxidation and electro- } \\
\text { Fenton oxidation }\end{array}$ & $>70 \% \mathrm{COD}$ & Eskandarloo et al. (2018) \\
\hline
\end{tabular}


treatment of oil-containing bilge wastewater in the presence of UV irradiation and $\mathrm{TiO}_{2}$ catalyst. Results demonstrated above $90 \%$ degradation of the wastewater by photocatalysis. However, the degradation increased to $99 \%$ upon combination with ultrafiltration nanocomposite membrane. More so, EC and nanofiltration integrated system in the presence of aluminium electrodes and flat-sheet membrane (NF 270) has been reported for the remediation of bilge wastewater (Akarsu et al. 2016). Maximum COD (74\%) (>150 mg/L) removal efficiency was recorded.

\section{Conclusions and recommendations for future opportunities}

Pollution from industrial oily wastewater has become a global phenomenon, causing adverse environmental and health hazards to the ecosystems. Over decades, conventional methods have been engineered to curb this menace, but proven to be less effective. Implementation of advanced treatment technologies provides an efficient approach in the removal of pollutants. In addition, the use of combined technologies has recently gained attention for complete remediation of toxic pollutants from high-strength oily wastewater. The selection of appropriate treatment method(s) depends on operational costs, wastewater composition, efficiency, regulatory limitation and end use of treated wastewater. The recommendations for the future direction of improving the treatment technologies include:

(1) The high operational and maintenance costs in the use of bioreactor could be circumvented through development of economical compact bioreactor with robust treatment efficiency. In addition, hybrid anaerobicaerobic bioreactor systems should be explored for enhanced removal of complex recalcitrant organic matter as well as reduction of energy consumption, odor and gas emissions.

(2) Membrane fouling encountered during industrial oily wastewater treatment could be eliminated by modification (surface and chemical) of the membrane, which enhances its performance by providing excellent permeation, biofouling resistance and hydrophilicity.

(3) Further research in electrochemistry should be geared towards development of electrodes with reasonable operational costs and stability.

(4) Photocalytic treatment of industrial oily wastewater could be improved by pre-treatment of the wastewater for the removal of $\mathrm{O} \& \mathrm{G}$ and SS using traditional physical separation approaches. More so, investigation on the modification of photocatalysts that are versatile under broad spectrum of operating conditions with better specific surface area and self-cleaning potential should be carried out.

(5) Special focus should be given to utilization of agricultural by-products as adsorbents for cost-effective, sustainable and eco-friendly remediation of industrial oily wastewater.

Funding The authors received no specific funding for this work.

\section{Declarations}

Conflict of interest The authors declare that they have no conflict of interests.

Open Access This article is licensed under a Creative Commons Attribution 4.0 International License, which permits use, sharing, adaptation, distribution and reproduction in any medium or format, as long as you give appropriate credit to the original author(s) and the source, provide a link to the Creative Commons licence, and indicate if changes were made. The images or other third party material in this article are included in the article's Creative Commons licence, unless indicated otherwise in a credit line to the material. If material is not included in the article's Creative Commons licence and your intended use is not permitted by statutory regulation or exceeds the permitted use, you will need to obtain permission directly from the copyright holder. To view a copy of this licence, visit http://creativecommons.org/licenses/by/4.0/.

\section{References}

Abadi SRH, Sebzari MR, Hemati M, Rekabdar F, Mohammadi T (2011) Ceramic membrane performance in microfiltration of oily wastewater. Desalination 265:222-228

Abd El-Gawad HS (2014) Oil and grease removal from industrial wastewater using new utility approach. Adv Environ Chem 2014:1-6

Abdelwahab O, Amin NK, El-Ashtoukhy ESZ (2009) Electrochemical removal of phenol from oil refinery wastewater. J Hazard Mater 163:711-716

Abou-Taleb EM, Hellal MS, Kamal KH (2020) Electro-oxidation of phenol in petroleum wastewater using a novel pilot-scale electrochemical cell with graphite and stainless-steel electrodes. Water Environ J 35:259-268

Abuhasel K, Kchaou M, Alquraish M, Munusamy Y, Jeng YT (2021) Oily wastewater treatment: overview of conventional and modern methods, challenges, and future opportunities. Water 13:980

Adetunji AI (2017) Treatment of lipid-rich wastewater using free and immobilized bioemulsifier and hydrolytic enzymes from indigenous bacterial isolates. Ph.D. Thesis, University of KwaZuluNatal, Durban, South Africa

Adetunji AI, Olaniran AO (2018) Treatment of lipid-rich wastewater using a mixture of free or immobilized bioemulsifier and hydrolytic enzymes from indigenous bacterial isolates. Desalin Water Treat 132:274-280

Adetunji AI, Olaniran AO (2021) Production and potential biotechnological applications of microbial surfactants: An overview. Saudi J Biol Sci 28(1):669-679

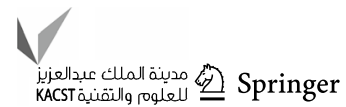


Affandi IE, Suratman NH, Abdullah S, Ahmad WA, Zakaria ZA (2014) Degradation of oil and grease from high-strength industrial effluents using locally isolated aerobic biosurfactant-producing bacteria. Int Biodeter Biodegrad 30:1-8

Agamuthu P (1995) Palm oil mill effluent-treatment and utilization. In: Sastry CA, Hashim MA, Agamuthu P (eds) Waste treatment plant. Narosa publishing house, New Delhi, pp 338-360

Ahmad AL, Bhatia S, Ibrahim N, Sumathi S (2005a) Adsorption of residual oil from palm oil mill effluent using rubber powder. Braz J Chem Eng 22:371-379

Ahmad AL, Sumathi S, Hameed BH (2005b) Residual oil and suspended solid removal using natural adsorbents chitosan, bentonite and activated carbon: a comparative study. Chem Eng J 108:179-185

Ahmad AL, Sumathi S, Hameed BH (2005c) Adsorption of residue oil from palm oil mill effluent using powder and flake chitosan: equilibrium and kinetic studies. Water Res 39:2483-2494

Ahmadun F, Pendashteh A, Abdullah LC, Biak DRA, Madaeni SS, Abidin ZZ (2009) Review of technologies for oil and gas produced water treatment. J Hazard Mater 170:530-551

Ahmed SN, Haider W (2018) Heterogeneous photocatalysis and its potential applications in water and wastewater treatment: a review. Nanotechnology 29:342001

Ahmed IH, Hassan AA, Sultan HK (2021) Study of electro-fenton oxidation for the removal of oil content in refinery wastewater. IOP Conf Series Mat Sci Eng 1090:012005

Akarsu C, Ozay Y, Dizge N, Gulsen HE, Ates H, Gozmen B, Turabik M (2016) Electrocoagulation and nanofiltration integrated process application in purification of bilge water using response surface methodology. Water Sci Technol 74:564-579

Al Zarooni M, Elshorbagy W (2006) Characterization and assessment of Al Ruwais refinery wastewater. J Hazard Mater 136:398-405

Al-Mutairi N, Bufarsan A, Al-Rukaibi F (2008) Ecorisk evaluation and treatability potential of soils contaminated with petroleum hydrocarbon-based fuels. Chemosphere 74:142-148

Al-Shahrani SS (2014) Treatment of wastewater contaminated with cobalt using Saudi activated bentonite. Alex Eng J 53:205-211

Asatekin A, Mayes AM (2009) Oil industry wastewater treatment with fouling resistant membranes containing amphiphilic comb copolymers. Environ Sc Technol 43:4487-4492

Aslan S, Alÿuz B, Bozkurt Z, Bakaoğlu M (2009) Characterization and biological treatability of edible oil wastewaters. Pol J Environ Stud 18:533-538

Asselin M, Drogui P, Brar SK, Benmoussa H, Blais JF (2008) Organics removal in oily wastewater by electrocoagulation. J Hazard Mater 151:446-455

Attiogbe FK, Glover-Amengor M, Nyadziehe KT (2007) Correlating biochemical and chemical oxygen demand of effluents- a case study of selected industries in Kumasi, Ghana. W Afri J Appl Eco 11:110-118

Awaleh MO, Soubaneh YD (2014) Wastewater treatment in chemical industries: the concept and current technologies. Hydrol Curr Res 5:164-175

Azhdarpoor A, Mortazavi B, Moussavi G (2014) Oily wastewater treatment using Pseudomonas sp. isolated from the compost fertilizer. J Environ Health Sc Eng 12:77

Bala JD, Lalung J, Ismail N (2015) Studies on the reduction of organic load from palm oil mill effluent (POME) by bacterial strains. Int J Recycl Org Waste Agric 4:1-10

Barambu NU, Bilad MR, Bustam MA, Kurnia KA, Othman MHD, Nordin NAHM (2020) Development of membrane material for oily wastewater treatment: a review. Ain Shams Eng J. https:// doi.org/10.1016/j.sej.2020.08.027
Benfer S, Popp U, Richter H, Siewert C, Tomandl G (2001) Development and characterization of ceramic nanofiltration membranes. Sep Purif Technol 22-23:231-237

Bhattacharya M, Biswas D, Sana S, Datta S (2015) Biodegradation of waste lubricants by a newly isolated Ochrobactrum sp.C1. 3 Biotech 5:807-817

Bienati B, Bottino A, Capannelli G, Comite A (2008) Characterization and performance of different types of hollow fibre membranes in a laboratory-scale MBR for the treatment of industrial wastewater. Desalination 231:133-140

Brillas E, Sires I, Oturan MA (2009) Electro-Fenton process and related electrochemical technologies based on Fenton's reaction chemistry. Chem Rev 109:6570-6631

Burns SE, Yiacoumi S, Tsouris C (1997) Microbubble generation for environmental and industrial separations. Sep Purif Technol 11:221-232

Cai L, Zhang Y, Zhou Y, Zhang X, Ji L, Song W, Zhang H, Liu J (2019) Effective adsorption of diesel oil by crab-shell-derived biochar nanomaterials. Materials 12:236

Cerqueira AA, Souza PSA, Marques MRC (2014) Effects of direct and alternating current on the treatment of oily water in an electroflocculation processs. Braz J Chem Eng 31:693-701

Chan YJ, Chong MF, Law CL (2010) Biological treatment of anaerobically digested palm oil mill effluent (POME) using a Lab-scale sequencing batch reactor (SBR). J Environ Mgt 91:1738-1746

Chanthamalee J, Wongchitphimon T, Luepromchai E (2013) Treatment of oily bilge water from small fishing vessels by PUF-immobilized Gordonia sp JC11. Water Air Soil Pollut 224:1601

Chaturvedi SI (2013) Mercury removal using Fe-Fe electrodes by electrocoagulation. Int J Modern Eng Res 3:101-108

Chavalparit O, Ongwandee M (2009) Optimizing electrocoagulation process for the treatment of biodiesel wastewater using response surface methodology. J Environ Sci 21:1491-1496

Chavan A, Mukherji S (2008) Treatment of hydrocarbon-rich wastewater using oil degrading bacteria and phototrophic microorganisms in rotating biological contactor: effect of $\mathrm{N}$ : $\mathrm{P}$ ratio. J Hazard Mater 154:63-72

Chen G (2004) Electrochemical technologies in wastewater treatment. Separ Purif Technol 38:11-41

Chen X, Chen G, Yue PL (2000) Separation of pollutants from restaurant wastewater by electrocoagulation. Sep Purif Technol 19:65-76

Chen X, Chen G, Yue PL (2002) Novel electrode system for electroflotation of wastewater. Environ Sc Technol 36:778-783

Chen L, Zhao S, Yang Y, Li L, Wang D (2019) Study on degradation of oily wastewater by immobilized microorganisms with biodegradable polyacrylamide and sodium alginate mixture. ACS Omega 4:15149-15157

Chong MN, Jin B, Chow CWK, Saint C (2010) Recent developments in photocatalytic water treatment technology: a review. Water Res 44:2997-3027

Chopra AK, Sharma AK, Kumar V (2011) Overview of electrolytic treatment: an alternative technology for purification of wastewater. Arch Appl Sci Res 3:191-206

Chowdhury P, Viraraghavan T, Srinivasan A (2010) Biological treatment processes for fish processing wastewater: a review. Bioresour Technol 101:439-449

Corti-Monzón G, Nisenbaum M, Villegas-Plazas M, Junca H, Murialdo S (2020) Enrichment and characterization of a bilge microbial consortium with oil in water-emulsions breaking ability for oily wastewater treatment. Biodegradation 31:57-72

de Almeida CC, da Costa PRF, de Macedo Melo MJ, dos Santos EV, Martínez-Huitle CA (2014) Application of electrochemical technology for water treatment of Brazilian industry effluents. J Mex Chem Soc 58:276-286 
De Felice B, Pontecorvo G, Carfagna M (2004) Degradation of wastewaters from olive oil mills by Yarrowia lipolytica ATCC 20255 and Pseudomonas putida. Acta Biotechnol 17:231-239

Deng Y, Zhao R (2015) Advanced oxidation processes (AOPs) in wastewater treatment. Curr Pollut Rep 1:167-176

Devi MG, Al-Hashmi ZSS, Sekhar GC (2012) Treatment of vegetable oil mill effluent using crab shell chitosan as adsorbent. Int $\mathbf{J}$ Environ Sci Technol 9:713-718

Di Giano FA (2004) Membrane bioreactor technology and sustainable water. Water Environ Res 76:195

Ding ZY, Frisch MA, Li L, Gloyna EF (1996) Catalytic oxidation in supercritical water. Ind Eng Chem Res 35:3257-3279

Diya'udeen BH, Daud WMAW, Abdul Aziz AR (2011) Treatment technologies for petroleum refinery effluents: a review. Proc Saf Environ Prot 89:95-105

Doshi B, Repo E, Heiskanen JP, Sirvio JA, Sillanpaa M (2018) Sodium salt of oleoyl carboxymethyl chitosan: a sustainable adsorption in the oil spill treatment. J Clean Prod 170:339-350

El-Ashtoukhy ESZ, El-Taweel YA, Abdelwahab O, Nassef EM (2013) Treatment of petrochemical wastewater containing phenolic compounds by electrocoagulation using a fixed bed electrochemical reactor. Int J Electrochem Sci 8:1534-1550

Eldin MSM, Ammar YA, Tamer TM, Omer AM, Ali AA (2017) Development of low-cost chitosan derivatives based on marine waste sources as oil adsorptive materials: preparation and characterization. Desalin Water Treat 72:41-51

El-Gohary F, Tawfik A, Badawy M, El-Khateeb MA (2009) Potentials of anaerobic treatment for catalytically oxidized olive mill wastewater (OMW). Bioresour Technol 100:2147-2154

Elimelech M, Philip WA (2011) The future of seawater desalination: energy, technology, and the environment. Sci 333:712-717

Emadian SM, Rahimnejad M, Hosseini M, Khoshandam B (2015) Investigation on up-flow anaerobic sludge fixed film (UASFF) reactor for treating low-strength bilge water of Caspian Sea ships. J Environ Health Sc Eng 13:23

Eskandarloo H, Selig MJ, Abbaspourrad A (2018) In situ $\mathrm{H}_{2} \mathrm{O}_{2}$ generation for de-emulsification of fine stable bilge water emulsions. Chem Eng J 335:434-442

Faibish RS, Cohen Y (2001) Fouling and rejection behavior of ceramic and polymer-modified ceramic membranes for ultrafiltration of oil-in-water emulsions and micro-emulsions. Colloids Surf A 191:27-40

Fakhru'l-Razi A, Pendashteh A, Abidin ZZ, Abdullah LC, Biak DRA, Madaeni SS (2010) Application of membrane-coupled sequencing batch reactor for oilfield produced water recycle and beneficial re-use. Bioresour Technol 101:6942-6949

Fazal S, Zhang B, Zhong Z, Gao L, Chen X (2015) Industrial wastewater treatment by using MBR (membrane bioreactor) Review study. J Environ Prot 6:584-598

Galvéz JM, Gómez MA, Hontoria E, González-Lopéz J (2003) Influence of hydraulic loading and air flow rate on urban wastewater nitrogen removal with a submerged fixed-film reactor. J Hazard Mater B101:219-229

Gargouri B, Gargouri OG, Gargouri B, Trabelsi SK, Abdelhedi R, Bouaziz M (2014) Application of electrochemical technology for removing petroleum hydrocarbons from produced water using lead dioxide and boron-doped diamond electrodes. Chemosphere 117:309-315

Garrido-Cardenas JA, Esteban-García B, Agüera A, Sánchez-Pérez JA, Manzano-Agugliaro F (2020) Wastewater treatment by advanced oxidation process and their worldwide research trends. Int J Environ Res Public Health 17:170

Giwa SO, Ertunc S, Alpbaz M, Hapoglu H (2012) Electroagulation treatment of turbid petrochemical wastewater. Int J Adv Sci Technol 5:23-32
Gryta M (2020) Separation of saline oily wastewater by membrane distillation. Chem Pap 74:2277-2286

Guo W, Ngo H, Vigneswaran S, Xing W, Goteti P (2008) A novel sponge-submerged membrane bioreactor (SSMBR) for wastewater treatment and reuse. Sep Sci Technol 43:273-285

Hamoda MF, Al-Ghusain IA (1998) Analysis of organic removal rates in the aerated submerged fixed film process. Water Sci Technol 38:213-221

Han M, Zhang J, Chu W, Chen J, Zhou G (2019) Research progress and prospects of marine oily wastewater treatment: a review. Water $11: 2517$

Hanafy M, Nabih HI (2007) Treatment of oily wastewater using dissolved air flotation technique. Energy sour Part A: Recovery Util Environ Eff 29:143-159

Hashim NA, Liu F, Li K (2009) A simplified method for preparation of hydrophilic PVDF membranes from an amphiphilic graft copolymer. J Membr Sci 345:134-141

He X, Zhang Q, Cooney MJ, Yan T (2015) Biodegradation of fat, oil and grease (FOG) deposits under various redox conditions relevant to sewer environment. Appl Microbiol Biotechnol 99:6059-6068

Hebbar HJ, Jayantha KS (2013) Oil and grease removal from wastewater using laterite as an adsorbent material. Int J Emerging Technol Adv Eng 3:654-657

Hebbar HJ, Jayantha KS (2014) Removal of organic based oil and grease from food service facility effluent using a laterite column. Am J Eng Res 3:48-50

Hejnfelt A, Angelidaki I (2009) Anaerobic digestion of slaughterhouse by-products. Biomass Bioenergy 33:1046-1054

Hoffmann MR, Martin ST, Choi W, Bahnemann DW (1995) Environmental applications of semiconductor photocatalysis. Chem Rev 95:69-96

Hosny AY (1992) Separation of oil from oilwater emulsions using an electroflotation cell with insoluble electrodes. Filtr Sep 29:419-423

Hua FL, Tsang YF, Wang YJ, Chan SY, Chua H, Sin SN (2007) Performance study of ceramic microfiltration membrane for oily wastewater treatment. Chem Eng J 128:169-175

Hudson N, Doyle J, Lant P, Roach N, Bruyn B, Staib C (2001) Sequencing batch reactor technology: the key to a BP refinery (Bulwer Island) upgraded environmental protection system-a low cost lagoon based retrofit. Water Sc Technol 43:339-346

Hussain A, Al-Yaari M (2021) Development of polymeric membranes for oil/water separation. Membranes 11:42

Hwu CS, Donlon B, Lettinga G (1996) Comparative toxicity of longchain fatty acids to anaerobic sludges from various origins. Water Sci Technol 34:351-358

Hwu CS, Tseng SK, Yuan CY, Kulik Z, Lettinga G (1998) Biosorption of long-chain fatty acids in UASB treatment process. Water Res 32:1571-1579

Hyun J, Jang H, Kim K, Na K, Tak T (2006) Restriction of biofouling in membranefiltration using a brush-like polymer containing oligoethylene glycol side chains. J Membr Sci 282:52-59

Ibrahim MY, Mostafa SR, Fahmy MFM, Hafez AI (2001) Utilization of electroflotation in remediation of oily wastewater. Sep Sci Technol 36:3749-3762

Ibrahim S, Wang S, Ang HM (2010) Removal of emulsified oil from oily wastewater using agricultural waste barley straw. Biochem Eng J 49:78-83

Ibrahim S, Ang HM, Wang S (2012) Adsorptive separation of emulsified oil in wastewater using biosorbents. Asia-Pacific J Chem Eng 7:S216-S221

Ibrahim DS, Lathalakshmi M, Muthukrishnaraj A, Balasubramanian N (2013) An alternative treatment process for upgrade of 
petroleum refinery wastewater using electrocoagulation. Pet Sci 10:421-430

Ibrahim I, Hassan MA, Abd-Aziz S, Shirai Y, Andou Y, Othman MR, Ali AAM, Zakaria MR (2017) Reduction of residual pollutants from biologically treated palm oil mill effluent final discharge by steam activated bioadsorbent from oil palm biomass. J Clean Prod 141:122-127

Izanloo H, Mesdaghinia A, Nabizadeh R, Naddafi K, Nasseri S, Mahvi AH, Nazmara S (2007) The treatment of wastewater containing crude oil with aerated submerged fixed-film reactor. Pakistan J Bio Sci 10:2905-2909

Izevbekhai OU, Gitari WM, Tavengwa NT, Ayinde WB, Mudzielwana R (2020) Response surface optimization of oil removal using synthesized polypyrrole-silica polymer composite. Molecules 25:4628

Jahi N, Ling ES, Othaman R, Ramli S (2015) Modification of oil palm plantation wastes as oil adsorbent for palm oil mill effluent (POME). Malays J Anal Sc 19:31-40

Jain K, Patel AS, Pardhi VP, Flora SJS (2021) Nanotechnology in wastewater treatment management: a new paradigm towards wastewater treatment. Molecules 26:1797

Jun KC, Abdul Raman A, Buthiyappan A (2020) Treatment of oil refinery effluent using bio-adsorbent developed from activated palm kernel shell and zeolite. RSC Adv 40:23510-24158

Kakavandi B, Ahmadi M (2019) Efficient treatment of saline recalcitrant petrochemical wastewater using heterogenous UV-assisted sono-Fenton process. Ultrason Sonochem 56:25-36

Kang J, Lu L, Zhan W, Li B, Li D, Ren Y, Liu D (2011) Photocatalytic pretreatment of oily wastewater from the restaurant by a vacuum ultraviolet/ $/ \mathrm{TiO}_{2}$ system. J Hazard Mater 186:849-854

Karakulski K, Gryta M (2017) The application of ultrafiltration for treatment of ships generated oily wastewater. Chem Pap 71:1165-1173

Karim MIA, Kamil AQA (1989) Biological treatment of palm oil mill effluent using Trichoderma viride. Biol Wastes 27:143-152

Ke C-Y, Qin F-L, Yang Z-G, Sha J, Sun W-J, Hui J-F, Zhang Q-Z, Zhang X-L (2021) Bioremediation of oily sludge by solid complex bacterial agent with a combined two-step process. Ecotoxicol Environ Saf 208:111673

Khalid FE, Lim ZS, Sabri S, Gomez-Fuentes C, Zulkharnain A, Ahmad SA (2021) Bioremediation of diesel contaminated marine water by bacteria: a review and bibliometric analysis. J Mar Sci Eng 9:155

Khondee N, Tathong S, Pinyakong O, Powtongsook S, Chatchupong T, Ruangchainikom C, Luepromchai E (2012) Airlift bioreactor containing chitosan-immobilized Sphingobium sp. P2 for treatment of lubricants in wastewater. J Hazard Mater 213-214:466-473

Korbahti BK, Artut K (2010) Electrochemical oil/water demulsification and purification of bilge water using $\mathrm{Pt} / \mathrm{Ir}$ electrodes. Desalination 258:219-228

Kumar PR, Chaudhari S, Khilar KC, Mahajan SP (2004) Removal of arsenic from water by electrocoagulation. Chemosphere 55:1245-1252

Kushwaha JP, Srivastava VC, Mall ID (2011) An overview of various technologies for the treatment of dairy wastewaters. Crit Rev Food Sci Nutri 51:442-452

Kusvuran E, Gulnaz O, Irmak S, Atanur OM, Yavuz HI, Erbatur O (2004) Comparison of several advanced oxidation processes for the decolorization of reactive red 120 azo dye in aqueous solution. J Hazard Mater b 109:85-93

Kuwahara Y, Kamegawa T, Mori K, Yamashita H (2010) Design of new functional titanium oxide-based photocatalysts for degradation of organics diluted in water and air. Curr Org Chem $14: 616-629$
Kuyukina MS, Krivoruchko AV, Ivshina IB (2020) Advanced bioreactor treatment of hydrocarbon-containing wastewater. Appl Sci 10:831

Kwon S, Sullivan EJ, Katz L, Kinney KA, Bowman RS (2008) Pilot scale test of a produced water-treatment system for initial removal of organic compounds. In: Proceedings of the SPE Annual Technical Conference and Exhibition, Denver, CO, USA, pp. 221-24 September 2008. SPE-116209-MS

Lathasree S, Rao N, Sivashankar B, Sadasivam V, Rengaraj K (2004) Heterogenous photocatalytic mineralization of phenols in aqueous solutions. J Mol Catal A: Chem 223:101-105

Ławniczak L, Woźniak-Karczewska M, Loibner AP, Heipieper HJ, Chrzanowski L (2020) Microbial degradation of hydrocarbons-Basic principles for bioremediation: a review. Molecules 25:856

Lee CW, Jang S-H, Chung H-S (2017) Improving the stability of coldadapted enzymes by immobilization. Catalysts 7:112

Li Q, Kang C, Zhang C (2005) Wastewater produced from an oilfield and continuous treatment with an oil-degrading bacterium. Proc Biochem 40:873-877

Lim CH, Ang JJ, Lau S, Tay MG (2017) Optimization of hydroxyl radical production using electro-Fenton method for chemical oxygen demand reduction in diluted palm oil mill effluent. Water Environ J 31:578-583

Lin SH, Chen ML (1997) Textile wastewater treatment by enhanced electrochemical method and ion exchange. Environ Technol 18:739-747

Lin CK, Tsai TY, Liu JC, Chen MC (2001) Enhanced biodegradation of petrochemical wastewater using ozonation and bac advanced treatment systems. Water Res 35:699-704

Lin L, Jiang W, Chen L, Xu P, Wang H (2020) Treatment of produced water with photocatalysis: recent advances, affecting factors and future research prospects. Catalysts 10:924

Liu GH, Ye Z, Tong K, Zhang YH (2013) Biotreatment of heavy oil wastewater by combined up-flow anaerobic sludge blanket and immobilized biological aerated filter in a pilot-scale test. Biochem Eng J 72:48-53

Lopez RJ, Higgins SR, Pagaling E, Yan T, Cooney MJ (2014) High rate anaerobic digestion of wastewater separated from grease trap waste. Renew Energy 62:234-242

Lürling M, Mucci M (2020) Mitigating eutrophication nuisance: in-lake measures are becoming inevitable in eutrophic waters in the Netherlands. Hydrobiologia. https://doi.org/10.1007/ s10750-020-04297-9

Madaki YS, Seong L (2013) Pollution control: how feasible is zero discharge concepts in Malaysia palm oil mills. Am J Eng Res 2:239-252

Mainardis M, Buttazzoni M, Goi D (2020) Up-flow anaerobic sludge blanket (UASB) technology for energy recovery: a review on state-of-the-art and recent technological advances. Bioengineering $7: 43$

Makisha N (2020) Research of oily wastewater treatment by means of membrane methods. Int Sci Technol Conf "Earth Sci 459:042015.

Malakahmad A, Hasani A, Eisakhani M, Isa MH (2011) Sequencing batch reactor (SBR) for the removal of $\mathrm{Hg}^{+}$and $\mathrm{Cd}^{2+}$ from synthetic petrochemical factory wastewater. J Hazard Mater 191:118-125

Mansouri AM, Shahrezaei F, Zinatizadeh AAL, Azandaryani AH, Pirsaheb M, Sharafi K (2014) Preparation of poly ethyleneimine $(\mathrm{PEI}) /$ nanotitania $\left(\mathrm{TiO}_{2}\right)$ multilayer film on quartz tube by layer-by-layer self-assembly and its applictions for petroleum refinery wastewater treatment. J Taiwan Insti Chem Eng 45:2501-2510 
Mansourizadeh A, Azad AJ (2014) Preparation of blend polyethersulfone/cellulose acetate/polyethylene glycol asymmetric membranes for oil-water separation. J Polym Res 21:1-9

Masuelli M, Grasselli M, Marchese J, Ochoa N (2012) Preparation, structural and functional characterization of modified porous PVDF membranes by $\gamma$-irradiation. J Membr Sci 389:91-98

Mearns AJ, Morrison AM, Arthur C, Rutherford N, Bissell M (2020) Effects of pollution on marine organisms. Water Environ Res 92:1510-1532

Merma AG, Santos BF, Rego ASC, Hacha RR, Torem ML (2020) Treatment of oily wastewater from mining industry using electrocoagulation: fundamentals and process optimization. J Mat Res Technol 9:15164-15176

Mittal P, Jana S, Mohanty K (2011) Synthesis of low-cost hydrophilic ceramic-composite membrane for treatment of oily wastewater. Desalination 282:54-62

Mohajeri S, Aziz HA, Isa MH, Zahed MA, Adlan MN (2010) Statistical optimization of process parameters for landfill leachate treatment using electro-Fenton technique. J Hazard Mater 176:749-758

Moslehyani A, Ismail AF, Othman MHD, Isloor AM (2015) Novel hybrid photocatalytic reactor-UF nanocomposite membrane system for bilge water degradation and separation. RSC Adv 5:45331-45340

Moslehyani A, Mobaraki M, Matsuura T, Ismail AF, Othman MHD, Chowdhury MNK (2016a) Novel green hybrid processes for oily wastewater photooxidation and purification from merchant ship. Desalination 391:98-104

Moslehyani A, Mobaraki M, Isloor AM, Ismail AF, Othman MHD (2016b) Photoreactor-ultrafiltration hybrid system for oily bilge water photooxidatiion and separation from oil tanker. React Funct Polym 101:28-38

Mota IO, Jose AC, Casqueira RG, Jnr AGO (2015) Study of electroflotation method for treatment of wastewater from washing soil contaminated by heavy metals. J Mater Res Technol 4:109-113

Moussavi G, Khosravi R, Farzadkia M (2011) Removal of petroleum hydrocarbons from contaminated groundwater using an electrocoagulation process: batch and continuous experiments. Desalination 278:288-294

Nahui FNB, Nascimento MR, Cavalcanti EB, Vilar EO (2008) Electroflotation of emulsified oil in industrial wastes evaluated with a full factorial design. Braz J Chem Eng 25:435-442

Nandi BK, Moparthi A, Uppaluri R, Purkait MK (2010) Treatment of oily wastewater using low cost ceramic membrane: comparative assessment of pore blocking and artificial neural network models. Chem Eng Res Des 88:881-892

Nopcharoenkul W, Netsakulnee P, Pinyakong O (2013) Diesel oil removal by immobilized Pseudoxanthomonas sp. RN402. Biodegradation 24:387-397

Nzila A, Thukair A, Saravanan S, Abdur Razzak S (2017) Characterization of aerobic oil and grease-degrading bacteria in wastewater. Environ Technol 38:661-670

Ochando-Pulido JM, Victor-Ortega MD, Hodaifa G, Martinex-Ferez A (2015) Physicochemical analysis and adequation of olive oil mill wastewater after advanced oxidation process for reclamation by pressure-driven membrane technology. Sci Total Environ 503-504:113-121

Ochoa NA, Masuelli M, Marchese J (2003) Effect of hydrophilicity on fouling of an emulsified oil wastewater with PVDF/PMMA membranes. J Membr Sc 226:203-211

Okiel K, El-Sayed M, El-Kady MY (2011) Treatment of oil-wateremulsions by adsorptiononto activated carbon, bentonite and deposited carbon. Egypt J Petr 20:9-15

Osibanjo O, Adie GU (2007) Impact of effluent from Bodija abattoir on the physicochemical parameters of Oshunkaye stream in Ibadan City, Nigeria. Afr J Biotechnol 6:1806-1811
Oswal N, Sarma PM, Zinjarde SS, Pant A (2002) Palm oil mill effluent treatment by a tropical marine yeast. Bioresour Technol 85:35-37

Padaki M, Murali RS, Abdullah MS, Misdan N, Moslehyani A, Kassim MA, Hilal N, Ismail AF (2015) Membrane technology enhancement in oil-water separation: a review. Desalination 357:197-207

Palenzuela-Rollon A, Zeeman G, Lubberding HJ, Lettinga G, Alaerts GJ (2002) Treatment of fish processing wastewater in a oneor two-step up-flow anaerobic sludge blanket (UASB) reactor. Water Sci Technol 45:207-212

Panizza M, Bocca C, Cerisola G (2000) Electrochemical treatment of wastewater containing polyaromatic organic pollutants. Water Res 34:2601-2626

Pardeshi SK, Patil AB (2008) A simple route for photocatalytic degradation of phenol in aqueous zinc oxide suspension using solar energy. Sol Energy 82:700-705

Parma S, Chowdhury P (2014) Preparation and characterization of microfiltration ceramic membrane for oily wastewater treatment. Int J Res Eng Technol 3:725-730

Pendashteh AR, Abdullah LC, Fakhru'l-Razi A, Madaeni SS, Abidin ZZ, Biak DRA (2012) Evaluation of membrane bioreactor for hypersaline oily wastewater treatment. Proc Saf Environ Prot 90:45-55

Pendergast MM, Hoek EMV (2011) A review of water treatment membrane nanotechnologies. Energy Environ Sc 4:1946-1971

Pereira MA, Cavaleiro AJ, Mota M, Alves MM (2003) Accumulation of long chain fatty acids onto anaerobic sludge under steady state and shock loading conditions: effect on acetogenic and methanogenic activity. Water Sci Technol 48:33-40

Pérez LS, Rodriguez OM, Reyna S, Sánchez-Salas JL, Lozada JD, Quiroz MA, Bandala ER (2016) Oil refinery wastewater treatment using coupled electrocoagulation and fixed film biological processes. Phys Chem Earth Parts a/b/c 91:53-60

Porwal HJ, Mane AV, Velhal SG (2015) Biodegradation of dairy effluent by using microbial isolates obtained from activated sludge. Water Resour Ind 9:1-15

Poulton SW, Krom MD, Rijn JV, Raiswell R (2002) The use of hydrous iron (III) oxides for the removal of hydrogen sulphide in aqueous systems. Water Res 36:825-834

Qin JJ, Oo MH, Tao G, Kekre KA (2007) Feasibility study on petrochemical wastewater treatment and reuse using submerged MBR. J Membr Sci 293:161-166

Rahi MN, Jaeel AJ, Abba AJ (2021) Treatment of petroleum refinery effluents and wastewater in Iraq: a mini review. IOP Conf Series Mat Sci Eng 1058:012072

Rajasulochana P, Preethy V (2016) Comparison on efficiency of various techniques in treatment of waste and sewage water- a comprehensive review. Resource-Efficient Technol 2:175-184

Ramli AN, Ghazi RM (2020) Removal of oil and grease in wastewater using palm kernel shell activated carbon. IOP Conf Series Earth Environ Sci 549:012064

Rastegar SO, Mousavi SM, Shojaosadati SA, Sheibani S (2011) Optimization of petroleum refinery effluent treatment in a UASB reactor using response surface methodology. J Hazard Mater 197:26-32

Razali MN, Yunus RM, Jemaat Z, Alias S (2010) Monoethanolamine wastewater treatment via adsorption: a study on comparison of chitosan, activated carbon, alum and zeolite. J Appl Sci 10:2544-2550

Rinzema A, Boone M, van Knippenberg K, Lettinga G (1994) Bactericidal effect of long chain fatty acids in anaerobic digestion. Water Environ Res 66:40-49

Robertson SJ, McGill WB, Massicotte HB, Rutherford PM (2007) Petroleum hydrocarbon contamination in boreal forest soils: a mycorrhizal ecosystems perspective. Biol Rev 82:213-240 
Rodgers M, Zhan XM, Gallagher B (2003) A pilot plant study using a vertically moving biofilm process to treat municipal wastewater. Bioresour Technol 89:139-143

Sagle AC, Wagner EMV, Ju H, McCloskey BD, Freeman BD, Sharma MM (2009) PEG-coated reverse osmosis membranes: desalination properties and fouling resistance. J Membr Sci 340:92-108

Saien J, Nejati H (2007) Enhanced photocatalytic degradation of pollutants in petroleum refinery wastewater under mild conditions. J Hazard Mater 148:491-495

Salahi A, Gheshlaghi A, Mohammadi T, Madaeni SS (2010) Experimental performance evaluation of polymeric membranes for treatment of an industrial oily wastewater. Desalination 262:235-242

Salahi A, Noshadi I, Badrnezhad R, Kanjilal B, Mohammadi T (2013) Nano-porous membrane process for oily wastewater treatment: optimization using response surface methodology. J Environ Chem Eng 1:218-225

Sanghamitra P, Mazumder D, Mukherjee S (2021) Treatment of wastewater containing oil and grease by biological method- a review. J Environ Sci Health A. https://doi.org/10.1080/10934529.2021. 1884468

Sani S, Dashti AF, Adnan R (2020) Applications of Fenton oxidation processes for decontamination of palm mill effluent: a review. Arab J Chem 13:7302-7323

Sarfaraz MV, Ahmadpour E, Salahi A, Rekabdar F, Mirza B (2012) Experimental investigation and modeling hybrid nano-porous membrane process for industrial oily wastewater. Chem Eng Res Des 90:1642-1651

Sayed K, Baloo L, Sharma NK (2021) Bioremediation of total petroleum hydrocarbons (TPH) by bioaugmentation and biostimulation in water with floating oil spill containment booms as bioreactor basin. Int J Environ Res Public Health 18:2226

Sekman E, Top S, Uslu E, Varank G, Bilgili MS (2011) Treatment of oily wastewater from port waste reception facilities by electrocoagulation. Int J Environ Res 5:1079-1086

Seveso D, Louis YD, Montano S, Galli P, Saliu F (2021) The Mauritius oil spill: what's next? Pollutants 1:18-28

Sharghi EA, Shourgashti A, Bonakdarpour B (2020) Considering a membrane bioreactor for the treatment of vegetable oil refinery wastewaters at industrially relevant organic loading rates. Bioprocess Biosyst Eng 43:981-995

Shende AD, Pophali GR (2020) Anaerobic treatment of slaughterhouse wastewater: a review. Environ Sci Pollut Res. https://doi. org/10.1007/s11356-020-10921-x

Shete BS, Shinkar NP (2013) Dairy industry wastewater sources, characteristics, and its effects on environment. Int J Curr Eng Technol 3:1611-1615

Shi Q, Su YL, Zhao W, Li C, Hu YH, Jiang ZY, Zhu SP (2008) Zwitterionic polyethersulfone ultrafiltration membrane with superior antifouling property. J Membr Sci 319:271-278

Shirazi M, Kargari A, Bazgir S, Tabatabaei M, Shirazi M, Abdullah M, Matsuura T, Ismail A (2013) Characterization of electrospun polystyrene membrane for treatment of biodiesel's waterwashing effluent using atomic force microscopy. Desalination 329:1-8

Shokrollahzadeh S, Azizmohseni F, Golmohammad F, Shokouchi H, Khademhaghigat F (2008) Biodegradation potential and bacterial diversity of a petrochemical wastewater treatment plant in Iran. Bioresour Technol 99:6127-6133

Sioi M, Bolosis A, Kostopoulou E, Poulios I (2006) Photocatalytic treatment of colored wastewater from medical laboratories: photocatalytic oxidation of hematoxylin. J Photochem Photobiol A: Chem 184:18-25

Sirés I, Brillas E, Oturan MA, Rodrigo MA, Panizza M (2014) Electrochemical advanced oxidation processes: today and tomorrow: a review. Environ Sci Pollut Res 21:8336-8367
Sokker HH, El-sawy NM, Hassan MA, El-Anadouli BE (2011) Adsorption of crude oil from aqueous solution by hydrogel of chitosan based polyacrylamide prepared by radiation induced graft polymerization. J Hazard Mater 190:359-365

Soltani S, Mowla D, Vossoughi M, Hesampour M (2010) Experimental investigation of oily water treatment by membrane bioreactor. Desalination 250:598-600

Srirangsan A, Ongwandee M, Chavalparit O (2009) Treatment of biodiesel wastewater by electrocoagulation process. Environ Asia 2:15-19

Suleimanov R, Gabbasova I, Sitdikov R (2005) Changes in the properties of oily gray forest soil during biological reclamation. Biol Bull 32:93-99

Sundar KP, Kanmani S (2020) Progression of photocatalytic reactors and its comparison: a review. Chem Eng Res Des 154:135-150

Sungur S, Özkan A (2017) Characterization of wastewaters obtained from Hatay tanneries. Nat Eng Sci 2:111-118

Suryanti V, Widjonarko DM, Windrawati Widyaningsih V (2017) Fabrication and characterization of immobilized biosurfactant produced by Pseudomonas aeruginosa grown on cassava industrial wastewater into activated allophane as an adsorbent. Mater Sci Eng 176:012005

Sutton NB, Maphosa F, Morillo JA, Al-Soud WA, Longenhoff AAM, Grotenhuis T, Rijnaarts HHM, Smidt H (2013) Impact of longterm diesel contamination on soil microbial community structure. Appl Environ Microbiol 79:619-630

Tetteh EK, Rathilal S (2020) Evaluation of different polymeric coagulants for the treatment of oily refinery wastewater. Cogent Eng 7:1785756

Tetteh EK, Ezugbe EO, Rathilal S, Asante-Sackey D (2020) Removal of COD and SO42-from oil refinery wastewater using a photocatalytic system-comparing $\mathrm{TiO} 2$ and zeolite efficiencies. Water 12:214

Tir M, Moulai-Mostefa N (2008) Optimization of oil removal from oily wastewater by electrocoagulation using response surface method. J Hazard Mater 158:107-115

Tiwari SP, Patel DR (2011) Removal of oil from oily effluents of North Gujarat fields (India) by electroflotation method. Ind J Sci Technol 4:1721-1725

Tobiszewski M, Tsakovski S, Simeonov V, Namiesnik J (2012) Chlorinated solvents in a petrochemical wastewater treatment plant: an assessment of their removal using self-organising maps. Chemosphere 87:962-968

Tomczak W, Gryta M (2021) Application of ultrafiltration ceramic membrane for separation of oily wastewater generated by maritime transportation. Sep Purif Technol 26:118259

Tran LH, Drogui P, Mercier G, Blais JF (2009) Electrochemical degradation of polycyclic aromatic hydrocarbons in creosote solution using ruthenium oxide on titanium expanded mesh anode. J Hazard Mater 164:1118-1129

Treviño-Roséndez J, Medel A, Meas Y (2021) Electrochemical technologies for treating petroleum industry wastewater. Curr Opin Electrochem. https://doi.org/10.1016/j.coelec.2021.100690

Trofimov SY, Rozanova M (2003) Transformation of soils properties under the impact of oil pollution. Eurasian Soil Sci 36:S82-S87

Tyagi M, da Fonseca M, de Carvalho C (2011) Bioaugmentation and biostimulation strategies to improve the effectiveness of bioremediation processes. Biodegradation 22:231-241

Ulucan K, Kurt U (2015) Comparative study of electrochemical wastewater treatment processes for bilge water as oily wastewater: a kinetic approach. J Electroanal Chem 747:104-111

Ulucan K, Kabuk HA, Ilhan F, Kurt U (2014) Electrocoagulation process application in bilge water treatment using response surface methodology. Int J Electrochem Sc 9:2316-2326 
Uludag-Demirer S, Olson N, Ives R, Nshimyimana JP, Rusinek CA, Rose JB, Liao W (2020) Techno-economic analysis of electrocoagulation on water reclamation and bacterial/viral indicator reductions of a high-strength organic wastewater-anaerobic digestion effluent. Sustainability 12:2697

USEPA (2004) Technical development document for the final effluent limitations guidelines and standards for the meat and poultry products point source category; final Rule. Fed Reg 69:54476-54555

Vasanth D, Pugazhenthi G, Uppaluri R (2011) Fabrication and properties of low cost ceramic microfiltration membranes for separation of oil and bacteria from its solution. J Membr Sci 379:154-163

Vendramel S, Bassin JP, Dezotti M, Jr Sant'Anna GL (2015) Treatment of petroleum refinery wastewater containing heavily polluting substances in an aerobic submerged fixed-bed reactor. Environ Technol 36:2052-2059

Viero AF, de MeloTorres TMAPR, Ferreira NR, Jr Sant'Anna GL, Borges CP, Santiago VMJ (2008) The effects of long-term feeding of high organic loading in a submerged membrane bioreactor treating oil refinery wastewater. J Membr Sc 319:223-230

Wahi R, Chuah LA, Choong TSY, Ngaini Z, Nourouzi MM (2013) Oil removal from aqueous state by natural fibrous sorbent: an overview. Sep Purif Technol 113:51-63

Wei L, Guo S, Yan G, Chen C, Jiang X (2010) Electrochemical pretreatment of heavy oil refinery wastewater using a three-dimensional electrode reactor. Electrochim Acta 55:8615-8620

Wei Y, Jin Y, Zhang W (2020) Treatment of high-concentration wastewater from an oil and gas field via a paired sequencing batch and ceramic membrane reactor. Int J Environ Res Public Health 17:1953

Wu L, Gang G, Wan J (2009) Biodegradation of oil wastewater by free and immobilized Yarrowia lipolytica W29. J Environ Sc 21:237-242

Xie WY, Zhong L, Chen JJ (2007) Treatment of slightly polluted wastewater in an oil refinery using a biological aerated filter process. Wuhan Univ J Nat Sci 12:1094-1098

Xu XH, Zhu XF (2004) Treatment of refectory oily wastewater by electro-coagulation process. Chemosphere 56:889-894

Yang S, Zhu W, Wang J, Chen Z (2008) Catalytic wet air oxidation of phenol over $\mathrm{CeO}_{2-} \mathrm{TiO}_{2}$ catalyst in the batch reactor and the packed-bed reactor. J Hazard Mater 153:1248-1253

Yang B, Chen GH, Chen GH (2012) Submerged membrane bioreactor in treatment of simulated restaurant wastewater. Sep Purif Technol 88:184-190
Yavuz Y, Koparal AS (2006) Electrochemical oxidation of phenol in a parallel plate reactor using ruthenium mixed oxide electrode. $\mathbf{J}$ Hazar Mater 136:296-302

Yavuz Y, Kopral AS, Ogutveren UB (2010) Treatment of petroleum refinery wastewater by electrochemical methods. Desalination 258:201-205

Yazdan MHS, Ahad MT, Jahan I, Mazumder M (2020) Review on the evaluation of the impacts of wastewater disposal in hydraulic fracturing industry in the United States. Technologies 8:0067

Yoshino Y, Suzuki T, Nair BN, Taguchi H, Itoh N (2005) Development of tubular substrates, silica based membranes and membrane modules for hydrogen separation at high temperature. J Membr Sci 267:8-17

Yousef R, Qiblawey H, El-Naas MH (2020) Adsorption as a process for produced water treatment: a review. Processes 8:1657

Yu L, Han M, He F (2017) A review of treating oily wastewater. Arabian J Chem 10:S1913-S1922

Yu Y, Zhang Y, Zhao N, Guo J, Xu W, Ma M, Li X (2020) Remediation of crude oil-polluted soil by the bacterial rhizosphere community of Suaeda salsa revealed by 16SrRNA genes. Int J Environ Res Public Health 17:1471

Yuan SH, Tong M, Wu GM (2011) Destabilization of emulsions by natural minerals. J Hazard Mater 192:1882-1885

Zhang T, Yan X, Sun DD (2012) Hierarchically multifunctional $\mathrm{K}$-OMS-2/ $/ \mathrm{TiO}_{2} / \mathrm{Fe}_{3} \mathrm{O}_{4}$ heterojunctions for the photocatalytic oxidation of humic acid under solar light irradiation. J Hazard Mater 243:302-310

Zhao X, Wang Y, Ye Z, Borthwick AGL, Ni J (2006) Oil field wastewater treatment in biological aerated filter by immobilized microorganisms. Proc Biochem 41:1475-1483

Zhou YB, Tang XY, Hu ZG, Fritschi S, Lu J (2008) Emulsified oily wastewater treatment using a hybrid-modified resin and activated carbon system. Separ Purif Technol 63:400-406

Zhu YZ, Wang D, Jiang L, Jin J (2014) Recent progress in developing advanced membranes for emulsified oil/water separation. NPG Asia Mater 6:e101

Zou XL (2015) Treatment of heavy oil wastewater by UASB-BAFs using the combination of yeast and bacteria. Environ Technol $36: 2381-2389$

Publisher's Note Springer Nature remains neutral with regard to jurisdictional claims in published maps and institutional affiliations. 